This is the peer reviewed version of the following article:

Athanasopoulou, A., Moss-Cowan, A., Smets, M., and Morris, T. (2017), Claiming the Corner Office: Female CEO Careers and Implications for Leadership Development, which will be published in final form in, Human Resource Management, (C) 2017 Wiley Periodicals, Inc. (in press). [DOI is pending]

This article may be used for non-commercial purposes in accordance with Wiley Terms and Conditions for Self-Archiving.

\title{
CLAIMING THE CORNER OFFICE: FEMALE CEO CAREERS AND IMPLICATIONS FOR LEADERSHIP DEVELOPMENT
}

\begin{abstract}
Drawing on evidence from a unique dataset of in-depth qualitative interviews with 12 female CEOs (and 139 male CEOs) of global corporations we explore what enables some women to become CEOs. By drawing on our data from male and female CEOs we set the scene by comparing the advice they would give to young women as they start their careers. We then focus the rest of our paper on the experiences and career trajectory of the 12 female CEOs. We make three theoretical contributions: We identify, at the individual level, how women can take active ownership of their careers as part of a self-acceptance process; how they can embrace gynandrous leadership as part of a self-development process where both feminine and masculine leadership behaviors are embraced, with the feminine being dominant to help move beyond gender stereotypes, and finally, how they translate leadership - rather than combine - genderbased behaviors as part of a self-management process to develop their unique leadership style. For each of these theoretical contributions at the individual level, we also provide two practical recommendations for HR practice and policy, one relating to the intra-organizational context and the second having institutional-level implications. We conclude by discussing implications for future research.
\end{abstract}

KEYWORDS: Gender, Chief Executive Officer, Top Management Teams, Leadership Development, Human Resources, Diversity, Research Methods \& Design - Qualitative research methodology. 


\section{Claiming the Corner Office: Female CEO Careers}

\section{Introduction: Women in the C-Suite and Female CEOs}

In recent decades, socioeconomic changes, demographic trends, and a growing need for diversity in the workplace have prompted more and more organizations to recruit, retain and promote women into senior executive ranks (Vinkenburg et al., 2000). Meanwhile, women have themselves demonstrated the ambition to take on senior positions, a trend reinforced by the higher rate of women graduating from universities and graduate programs than men (Grant Thornton, 2016). Nonetheless, female representation in senior management positions remains relatively low, at just 9\% of the global pool of CEOs or managing directors (ibid: 10). Media and academic publications often showcase these few women who do manage to break the glass ceiling to become CEOs as the exceptions that prove the rule (Glass \& Cook, 2016; Cook \& Glass, 2014a; see also the experiences of female CEOs at Xerox; Doherty, 2012; Lubin, 2016). The rarity of female CEOs and the lack of studies on them mean we still have very limited insights into how women at the top of organizations perceive their career success - or its implications for others.

This paper turns the spotlight onto those relatively few women who have become CEOs. While much of the gender and leadership literature discusses structural and other barriers that limit women’s progress through the ranks (e.g., Ibarra, 2011), we focus instead on female CEOs’ own accounts of their success. Accordingly, we embarked on an in-depth study of the leadership journey of 12 female CEOs, most of whom lead large, global corporations. We did so as part of a larger study on the same topic, covering a total of 151 global CEOs - 12 female and 139 male. While interviews with these 12 female CEOs form our core data for this study, we also draw on a specific segment of our data from the remaining 139 male CEOs to scope how they perceive their female peers, arguably an essential factor in the context within which these female CEOs operate. 


\section{Claiming the Corner Office: Female CEO Careers}

Our guiding research questions are: How do female CEOs explain their own career success?

\section{What are the wider implications for women's leadership development?}

By “career success” we refer here specifically for the purpose of this research to how these

female leaders became CEOs in their organizations. From this study we make several theoretical contributions: We identify - at the individual level - how women can take active ownership of their careers as part of a self-acceptance process. We explain how they can move beyond gender stereotypes by enacting what we term gynandrous leadership (gyne - female, andro - male) in a self-development process to embrace both feminine and masculine leadership behaviors but where the female aspects take precedence, in deliberate contrast to stereotypical conceptions of androgynous leadership. Finally, we argue that in their self-management process, women translate - rather than combine - gender-based behaviors, meaning that they translate behaviors that are stereotypically masculine and they perform them in such a way that feels authentic and that harmoniously blend into their gynandrous leadership repertoire.

Our study is guided by two themes: the contextual and the personal aspects of women's (and female CEOs' specifically) career progression. The former takes an 'outside-in' perspective on women's leadership and their interaction with their environment, while the latter takes an 'insideout' perspective on the experiential and behavioral themes that shape how these women become leaders. With that in mind, the following section presents the theoretical background to our research. We start by briefly outlining the facilitators and barriers to female career progression at a contextual and personal level. This sets the groundwork for the first of our two research questions on how female CEOs explain their own career success. We then provide an overview of key themes from the literature on women and leadership including men's and women’s perceptions of women as leaders as well as themes relating to women’s leadership development. This sets the groundwork for the second research question on women's leadership development. 


\section{Claiming the Corner Office: Female CEO Careers}

In order to examine 'career success', we first need to establish what we conceptually mean by 'career'. Inkson et al. (2012: 324) stress how a career “uniquely connects individuals with organizations and other social institutions over time”. The emergence of the concept of a ‘boundaryless career' where individuals are seen as “proactive creators of their own careers” - as opposed to the traditional organizational careers - has changed the field's understanding of what career means (ibid: 325). As part of a boundaryless career framing, Arthur \& Rousseau (1996: 6; in Inkson et al. (2012: 326) identified the following characteristics: mobility across separate employers, validation from outside the present employer, the sustaining of external networks and information as critical aspects of career-building, non-hierarchical reporting and advancement, the precedence of personal or family reasons leading to rejection of career opportunities and finally, career-building free of structural constraints. This notion of a lack of boundaries has been criticized later by Inkson et al. (2012), who contested in favor of a framing that rests in-between a boundaryless career and a traditional organizational career framing. Yet, the value of a full or partially boundaryless careers framing is important as it acknowledges the agentic role of individuals as far as their careers are concerned, a theme that we find central to this study. Careers are now characterized as cycles of career stability and professional transitions (Ibarra \& Petriglieri, 2010), whether within or between organizations calling for individuals’ “engagement in provisional but active trial of possible future selves”, that is, identity play (ibid: 10). Drawing on these, we define “career” as having strong agentic nature and being characterized by flexibility and variety, both within and across organizations. 
Claiming the Corner Office: Female CEO Careers

\section{Facilitators and Barriers to Women's Career Progression: Contextual and Personal}

\section{Themes}

\section{The Role of Social Context}

The social context in which a woman is brought up and works is instrumental in the development of her leadership potential and job opportunities (Cook \& Glass, 2014a and 2014b; Kanter, 2013; Kossek et al., 2017; Ryan \& Haslam, 2007). Gendered patterns in the accumulation of career relevant experiences accrue from birth into women’s working lives, setting limitations on women's ability to access CEO roles and the availability of CEO appointments (Fitzsimmons et al., 2014). Within the organizational context, limited access to networks and lack of sponsorship are said to impede women’s career advancement. Ibarra et al. (2010), for example, found that compared with their male peers, high-potential women are over-mentored and undersponsored and that this impedes their career advancement. Without sponsorship, women are less likely than men to be appointed to top roles and more reluctant to try for them (ibid). Women and racial minority first-time directors receive comparatively fewer appointments to other boards compared to other peers (McDonald \& Westphal, 2013). It requires a significant degree of selfdevelopment among women to overcome such barriers by actively developing networks that help their careers and seeking out mentors when their organization does not formally provide such opportunities. Even when they do, results are mixed. For instance, Arnold and Johnson (1997) found limited benefits from mentoring, regardless of gender. Protégés only benefited from mentoring when the mentor was influential, a resource which women cannot easily access. Results from mentoring are also context-sensitive. For example, Leck \& Orser (2013) observed that perceptions of risk inherent to mentoring (i.e., issues of trust in the mentoring relationship) are influenced by time, major events and gender. 


\section{Claiming the Corner Office: Female CEO Careers}

Women may also inherit jobs that risk challenging their leadership capability, a phenomenon known as the "glass cliff” (e.g., Glass \& Cook, 2016; Mulcahy, \& Linehan, 2014; Ryan \& Haslam, 2007; ). Women are placed in precarious leadership positions "setting them up for failure and pushing them over the edge” (Sabharwal, 2015: 399). They often have neither the support nor the authority to accomplish their strategic goals, resulting in female leaders having shorter tenures compared to their male peers (Glass \& Cook, 2016). Alongside the traditional mantra of "think manager-think male" (Schein et al., 1996), a new one is "think crisis-think female” (Ryan \& Haslam, 2007: 550; see also Koenig et al., 2011).

Other elements that may facilitate or inhibit women's careers are the trade-offs they make on work-life balance issues - occupying the space between the context in which women operate and their own personal experiences. In trying to balance work and non-work domains, women often experience negative psychosocial (e.g., job satisfaction and self-esteem) and economic (e.g., career advancement) consequences (Hopkins \& O’ Neil, 2007), although some evidence suggests life roles may in fact benefit managerial roles (Ruderman et al., 2002). Still, double standards seem to apply on work-life balance between genders. A study by Groysberg \& Abrahams (2014) showed that male executives tend to praise their partners for positively contributing to their careers, whereas female executives praise their partners for not interfering in their career. In addition, organizations often send conflicting messages as to how supportive they are of worklife balance (Wheatley, 2012). For women to reach a level of self-acceptance in which they see such trade-offs as positive requires a lot of work. Insofar as they take primary responsibility for raising families by taking time off full-time work, this may delay or stall their career progress relative to male peers or women without children, and make it difficult to 'catch up', either when working part-time or when they return to full-time work. 


\section{Claiming the Corner Office: Female CEO Careers}

\section{Personal Level Facilitators and Barriers: Taking Control of One’s Career}

At the personal level, limited access to career relevant experiences in childhood, adolescence and in organizations leads to on-going limitations in access to resources throughout women's careers (van Staveren, 2013). Certain behaviors typically observed more in women are also said to undermine their career chances, such as disinclination to self-promote (Budworth \& Mann, 2010), limiting volubility (i.e., the time spent talking; Brescoll, 2011) and invisibility (i.e., "states of exclusion” or difference because of a lack of women in leadership roles; Stead, 2013). In short, whether consciously or unconsciously, women tend to undermine their own efforts and contributions. This can be explained by what Kets de Vries (2005: 110) has termed the "neurotic impostor” syndrome which “causes many talented, hardworking, and capable leaders - men and women who have achieved great things - to believe that they don't deserve their success”. Likewise, women leaders get 'trapped' in an identity conflict caused by behavioral expectations (e.g., Ibarra \& Petriglieri, 2007). They are often “punished” for “violating” gender stereotypes (Bray, 2013: 3), and the stress of conformity usually weakens their leadership performance, helping confirm negative views about them as leaders. Thus, these self-undermining behaviors require extensive self-management by women to improve and realize their leadership potential.

\section{Women as Leaders: Leadership Style and Gender Perceptions of Effectiveness}

In this study, we adopt Northouse’s (2016: 32) definition of leadership as a process that involves influence, takes place in groups and involves common goals. Scholarly work on leadership boasts a wide array of theories on how successful leadership happens, including traitbased, leader-follower, situational and authenticity perspectives (see Northouse, 2016). Limited theory, however, exists that addresses the leader's gender as a variable that affects leadership effectiveness. Eagly and colleagues’ work on role congruity, according to which 


\section{Claiming the Corner Office: Female CEO Careers}

prejudice emerges from an incongruity between group stereotypes and role characteristics, is indicative of this (Eagly \& Karau, 2002; Koenig \& Eagly, 2014; Koenig et al., 2011). Eagly \& Karau (2002) observed prejudice toward women, who were perceived less favorably than men as potential leaders, with their actual leadership behavior also being evaluated less favorably. Koenig et al.’s (2011) meta-analysis confirmed overall masculinity of leader stereotypes but also showed a decrease in such a gendered construal over time. Nevertheless, the meta-analysis showed that men would tend to have a more masculine construal of leadership than women (ibid). The social context also plays a role in this construal, with leaders being seen as less masculine in specific settings (e.g., in educational institutions), as well as in moderate-status versus high-status leader roles (ibid). These studies confirm that, with few exceptions or variations, a leader is tacitly assumed to be a male leader, or at best, gender-less. A similar “implicit masculine bias” afflicts studies of top management decision-making due to the dominance of male CEOs (Ho et al., 2015). In contrast, much of the gender and leadership literature has focused on similarities and differences in each gender's leadership style as well the gender effect on leader effectiveness. With few exceptions (e.g., Dobbins \& Platz, 1986; van Engen et al., 2001), most studies conclude that women have a predominantly transformational leadership style (Bass et al., 1996; Druskat, 1994; Eagly et al., 2003; Lopez-Zafra et al., 2012), while male leaders use transactional terms when describing their own style (Rosener, 1990). Yet, when transformational leadership is linked to leader effectiveness, the link appears stronger for male leaders (Douglas, 2012), although "there is no evidence that women are incompetent as leaders, whether measured by effectiveness or by the use of optimal styles such as transformational leadership” (Hyde, 2014: 387). Several studies argue that similarities between men and women as leaders are greater than their differences (e.g., Powell, 1990; Vinkenburg et 


\section{Claiming the Corner Office: Female CEO Careers}

al., 2000), and more recent studies concluded that these differences are relatively small (Eagly \& Johannesen-Schmidt, 2007; Eagly, 2013).

Women are more likely than men to combine feminine and masculine leader behaviors in an androgynous leadership style that is predominantly transformational. They "act as inspirational role models, foster good human relationships, develop the skills of followers, and motivate others to go beyond the confines of their job descriptions” (Eagly, 2013: 5). Consistent with stereotyping, female leaders are expected to excel at 'nurturing' competencies (e.g., developing others and relationship-building) and outscore men on those abilities. Moreover, each gender tends to enact similar roles somewhat differently (Eagly \& Johannesen-Schmidt, 2007). This enactment is also perceived differently by subordinates. For instance, sensitivity is more strongly associated with female leadership, whereas strength and tyranny are more strongly associated with male leadership (Johnson et al., 2008).

Looking at particular leadership competences, women are rated more highly in 12 of the 16 competencies relating to outstanding leadership and particularly in 'taking initiative' and 'driving for results', which have been traditionally considered male strengths; yet, men significantly outscored women in their ability to develop a strategic perspective (Zenger \& Folkman, 2011; 2012). Similarly, Ibarra \& Obodaru's (2009) analysis of thousands of 360-degree assessments showed that women outshine men in all areas but one: 'vision'.

Gender and leadership scholars have examined how each gender perceives the leadership effectiveness of their own and the opposite gender and confirmed the prevalence of gender stereotypes. Eagly et al.’s (1992) meta-analysis showed a small overall tendency for female leaders to be evaluated less favorably than men, particularly when exhibiting masculine styles, such as autocratic or directive styles, compared to more feminine ones. Females also seem to be the least preferred leader when study participants are asked to state gender preference (Elsesser \& 


\section{Claiming the Corner Office: Female CEO Careers}

Lever, 2011). Finally, women tend to under-value themselves: men rate themselves as significantly more effective than women rate themselves as being (Paustian-Underdahl et al., 2014).

\section{The Critical and Practice Turns on Gender and Leadership Studies}

While much of the gender and leadership literature is preoccupied with leadership style differences between genders and how followers perceive leader effectiveness as mediated by leaders’ and followers’ gender, the relatively recent practice turn in organization studies (Schatzki et al., 2001; Whittington, 2002) has also had an effect on how gender and leadership are conceptualized. Leadership-as-practice (Raelin, 2016; Harrison, 2016) is now introduced as a promising approach to theorizing leadership that allows to better capture the dynamics of organizational practices and organizing (Simpson et al., 2017). The links between context, practice and gender appear to invite new ways of understanding gender and leadership. Research suggests that leadership is enacted in different ways depending on context (Schedlitzki et al., 2017). More specifically, gendered leadership and non-leadership are found to be interconnected with the social contexts within which they take place, and the way key organizational actors make sense of such leadership leads to its enactment into organizational policies (e.g., gender equality policies) (Hearn \& Piekkari, 2005).

The gender and leadership literature has taken a more critical perspective (Collinson, 2017), particularly recently, as a way to shift the field's focus beyond the "dualistic thinking that leaves leaders trapped within their sex role stereotype, reproducing the inequalities of the binary” (Leitch \& Stead, 2016). Such an approach invites scholars to see gender and leadership as socially constructed and encourages the field to focus instead on what West \& Zimmerman (1987; in Leitch \& Stead, 2016: 127) have described as the “doing of gender”. Such an approach invites the gender and leadership field to explore how gender becomes the subject of (re)creation 


\section{Claiming the Corner Office: Female CEO Careers}

and negotiation and is sustained within various social contexts (Leitch \& Stead, 2016:127). This new interest in the performativity of leadership has triggered discussions on the reframing of leadership in such a way as to distinguish between "leadership as a set of practices” and "leadership in the flow of practice” (Simpson et al., 2017: 1). In the latter perspective, aspects of leadership performativity such as the nature of “leadership talk” (ibid) as well as the use of leadership discourse in best-selling leadership texts (Ferry, 2017) take center stage.

\section{Developing Female Leaders}

Leadership development is the process of "expanding the collective capacity of organizational members” in order to effectively engage in leadership roles and processes (Day, 2000: 582). Day (2000: 582) identifies a “dearth” of research directly relating leadership development to gender. He distinguishes 'leader development', i.e., the development of the individual skills, abilities and knowledge of an organization's human capital, from 'leadership development', i.e., the development of the organization's social capital (ibid). We have noted above the research on networks and gender that will impinge on women’s leadership development. In terms of leader development, prior research suggests that, while women can have access to leader development (e.g., training programs), these do not sufficiently help develop requisite "leader identity" due to limited role models, gendered career paths and cultural biases (Ely et al., 2011: 476-479).

To summarize, much of the existing literature focuses on structural, cultural and organizational factors that might explain the still limited participation of women in the most senior ranks of organizations. Here, we take a different, complementary tack and look at the accounts of a small number of women who have made it to the top, to explore how they explain their career trajectory and success. Specifically, we examine how female CEOs explain their own 


\section{Claiming the Corner Office: Female CEO Careers}

career success and what the wider implications are for women's leadership development from an individual perspective as well as from an HR policy and practice perspective.

\section{Methods}

\section{Sample, Methods and Data Collection}

This study is part of a larger research project that examines the question, "How do CEOs develop the competence to lead in a changing world?” We approached that question qualitatively, conducting rich, personal conversations with 151 CEOs (139 male and 12 female) representing a wide range of sectors from around the world, generating unique and detailed insights into how global CEOs lead. These in-depth, semi-structured interviews were, with few exceptions, conducted face-to-face, and we append the interview schedule that guided our conversations, as well as the invitation letter (Appendix I). All interviews were transcribed verbatim and anonymized prior to analysis. To protect anonymity, CEOs were randomly assigned a number from 1-200, rather than sequential numbers, as personal identifiers. We use these numbers in the findings section to identify the different voices in our sample. Assured of their anonymity, the CEOs provided in-depth reflections of their experience of leadership. Open-ended questions allowed them free rein to elaborate.

The focus of this paper is on the 12 female CEOs. We summarize here their profile and include the male demographics in parentheses for comparison. On average, these female CEOs have a tenure in the job of nearly 5 years (6.4 years). The companies they lead earn revenues that range from $\$ 36$ million to $\$ 76$ billion, with an average of $\$ 15$ billion (\$14 billion); and they employ an average of 36,830 people, with totals ranging from 300 to 244,000 (47,000 people). This global research effort included four female informants from Asia-Pacific (30), four from North America (35), one from Europe (45), one from Latin America (11), and two from the 


\section{Claiming the Corner Office: Female CEO Careers}

Middle East and North Africa (14 - plus four CEOs from sub-Saharan Africa). Here, we draw on a total of 671 minutes of interview data from female CEOs, or 11.2 hours. Interview length ranged from 38 to 83 minutes, with an average of 56 minutes.

The participants in our study are all part of the business elite, which is notoriously difficult to access for research (Kakabadse et al., 2015; Thomas, 1993). Yet, the broader view they bring in comparison to other interviewees makes their perceptions especially valuable (Marshall \& Rossman, 1999). The total number of interviews obtained here is unusually large for such indepth qualitative studies of CEOs. To achieve this unprecedented scale, the authors drew on the joint resources of a Business School specializing in leadership education and one of the world's largest executive search firms. These organizations solicited interviews with their contacts on behalf of the authors. We purposefuly sought to recruit participants from as wide a variety of industries as possible and with as much global outreach from some of the largest corporations globally. In collaboration with the executive search firm and the Business School we listed the types of companies, industries and the global outreach we aimed for to maximize balance and breadth in our sample and recruited participants accordingly. The relatively small sample size of 12 female CEOs simply reflects the underrepresentation of women in the corner office.

According to Grant Thornton (2016) only 9\% of CEOs or managing directors globally are women, and in the G7 just 7\% of women in senior management are CEOs. Our sample of female CEOs - 8\% of the 151 CEOs - is representative of this reality.

\section{Data Analysis}

Given that underrepresentation, and the important implications their journeys may have for advancing leadership opportunities for women, the narratives of top female executives can be said to provide an 'extreme case'. Extreme cases are appreciated because they can reveal insights 


\section{Claiming the Corner Office: Female CEO Careers}

that may be hard to isolate in more familiar conditions (Eisenhardt, 1989). The goal of qualitative research is analytical generalization (Yin, 2013) rather than statistical generalization, and this is particularly appropriate for an extreme case, where the sample size is small. The qualitative study design addresses concerns for which statistical techniques are not always capable of providing the “right answers” (Welbourne, 2012). In this case, counting occurrences risks underemphasizing key insights or overemphasizing relatively small differences (Pratt, 2009). In line with this qualitative philosophy, we seek analytic insights and present our findings from the perspective of those studied (ibid: 856). In this method, researchers study the participants’ view of events, focusing “as much as possible on the participants' view of the situation” (Creswell, 2003: 8).

We used an inductive, open-ended strategy in data analysis with the help of NVivo qualitative data analysis software. We initially coded the interviews according to the themes included in our schedule (Appendix I). On that basis, we started coding each answer, developing new themes and sub-themes as NVivo parent and child nodes. In order to make sure we had a mutual understanding of the coding and the themes assigned to each code, we cross-checked the coding of the first five interviews so that they were coded by at least two members of the team, and any coding variations were discussed and resolved. This cross-checking continued regularly throughout the data analysis to ensure seamless understanding of the coding approach and emerging concepts. This often led to merging codes that closely overlapped. We adopted this analysis process for the 151 interviews, which allowed us to examine the differences between male and female CEOs. We then conducted a more focused analysis of the female CEO interviews, re-reading them and following a similar iterative process. We initially had ten parent

nodes (e.g., qualities of future CEOs, defining moments etc.) that reflected the different themes in our interview protocol, and we identified child nodes for each parent node. For instance, for the parent node of 'defining moments’ child nodes included two second-order themes: work-related 


\section{Claiming the Corner Office: Female CEO Careers}

and personal life-related. All but one female CEO referred to professional life defining moments and we had child nodes attached to the 'professional life' child node that included which experiences were positive and which negative. We also visually mapped the different themes in Excel.

Through reflexivity and the use of tools such as theoretical memoranda (Martin \& Turner, 1986), we iterated back and forth between data and literature. Through this abductive process (Blaikie, 2000), we began to develop theory (Locke, 2001). This involved switching from the question-based thematic coding drawn from the protocol to a more refined coding based on emerging themes, developing new coding categories. This process led to the first-order concepts shown in the first column of Table 1, which were then further developed into ten second-order themes, included in the second column of Table 1 (defining moments, confidence barriers, career barriers, etc.).

\section{---Insert Table 1 about here---}

We also observed that these second-order themes would either reflect the perceived locus of influence as residing with the woman herself, relevant to experiences and behaviors she controlled as an individual, or contextual themes, influences from the environment that women had to accept and cope with, as indicated in the third column of Table 1. By categorizing raw data and then linking categories to themes we achieved greater levels of abstraction, leading us to develop our theoretical framework (Pratt et al., 2006). We moved from open codes, to first-order concepts, which were abstracted into second-order concepts, and eventually grouped into three aggregate theoretical dimensions (fourth column, Table 1): self-acceptance, self-development and self-management. For example, we heard that, compared to men, women tend to overemphasize their shortcomings when applying for a position. Interviewees called on women to "think of 


\section{Claiming the Corner Office: Female CEO Careers}

themselves as leaders" and "ask for the job", which we subsumed under the second-order theme of 'confidence barriers' as part of the personal category of control. Women had to overcome these confidence barriers to develop as leaders, and thus 'self-acceptance' emerged as an aggregate theoretical dimension (fourth column, Table 1). We now briefly explain all three aggregate dimensions:

Self-Acceptance: A cluster of themes emerged around processes by which female CEOs came to recognize and accept their own leadership potential, and learned to cope with their own and others' expectations about their priorities on work and family. Overcoming confidence barriers emerged as key, alongside learning to cope with career and family challenges as they were taking on greater responsibilities. For this cluster we drew primarily on questions about CEOs’ defining moments as well as the advice they would give to aspiring CEOs, particularly females.

Self-Development: A second theme focused on processes of development, both in preparation for the CEO role and on the job, as women grew into the role. At the personal level they spoke of developing 'big picture’ capabilities associated with the strategic skills needed to perform the CEO job. We also saw them develop networks to build knowledge and human capital rather than political capital. From a contextual perspective, they spoke about being mentored and about their own contextual influence by serving as role models and mentors to other women. This thematic code sees them developing a uniquely feminine style of transformational leadership, which puts emphasis on role modeling and communication. For this cluster we drew primarily on questions about the qualities and tools required for the job, the best and worst advice they had received, what they wish they had known before taking the job, and what sources of support they rely on.

Self-Management: A final cluster focused around CEOs learning to lead and manage their own careers, both before they took up the CEO role as well as while being on the job. Female CEOs were cognizant of expectations around women's personal demeanor and reported on the 


\section{Claiming the Corner Office: Female CEO Careers}

delicate balance they had to strike to be accepted as leaders. Part of this preparation involved ‘toughening up’, shedding stereotypically female attitudes and work habits. In terms of contextual influences, their trajectory included learning the skills and behaviors needed to take on progressively more senior roles, for instance around risk and decision-making. Here, we drew primarily on what were their toughest decisions and how they coped with them and the associated uncertainties.

Of course, for each cluster we also drew on questions that cut across themes. For instance, the question on toughest decisions relates to both the self-management and self-development clusters. Similarly, while we present these themes in the order discussed above, in fact, selfacceptance was a necessary first step on their paths to leadership, but self-development and selfmanagement were iterative and ongoing. We discuss these two last 'selves-' in the linear order shown, but that is an artificial organizational scheme, adopted in the interest of clarity.

\section{Findings}

The observations from the literature showcase how genders continue to think in stereotypical ways, and hence we decided to set the scene for our findings with data on what advice male and female CEOs would provide to young women aspiring to be CEOs.

"I think that [women are]...going to run the show, if they don't already. You know, a woman leader is by far potentially more powerful than a male leader ... yet we live in a male-dominated culture where the expectation is that men are in charge ... it's sort of like running a race and I think the men are at a disadvantage but women just haven't been told that" [019].

"I have a chip on my shoulder for women I think, generally speaking, because I saw what [my mother] ...went through in her life in the 70s where she was ...absolutely the smartest woman in the room who couldn't get a promotion to save her life and the incredibly ridiculous chauvinism that existed in the world then, even worse than now - although now it's just quiet, but it's still there. So I saw that, and so my advice [to female students] would be ...be more prepared, because, guess what? The world has not changed all that much" [165]. 


\section{Claiming the Corner Office: Female CEO Careers}

Which of these two quotes - both from male CEOs - better reflects the reality for young ambitious women today? The larger study this paper draws from was spurred by a strong sense that the job of CEO is undergoing a period of change. One potential area of change is women's future representation among CEOs. What did these 151 sitting executives, both male and female, believe were the opportunities women faced in charting a path to the corner office, and what were the challenges to overcome? To that end, we included in our interview protocol a question seeking their advice for a class of undergraduates who aspired to the role. After asking this general question, we followed up with a gender-specific probe on what they would advise the female students in that hypothetical class - or their daughter. We begin the presentation of our findings with an overview of the responses CEOs from the entire dataset, both male and female, gave to this gender-specific probe. We start by presenting the responses we got to the genderspecific probe from male CEOs. Next, we move on to present the responses female CEOs gave to the gender-specific probe. We conclude the section by presenting an in-depth analysis of our female informants’ insights in response to other questions from the interview protocol.

In including the male responses to the gender-specific probe here, we acknowledge the key role they have played in women's advancement, a role they will continue to play given their ongoing dominance in leadership positions. Their views are also pertinent because they form a cohort of current CEOs who ascended through the ranks in parallel and have seen many women stall at lower levels. We seek to explore why men think this happens to women more than men. By looking at male CEOs’ responses to this gender-specific question, we shed light on their contextual perspective ‘from the outside’. Then, we examine women’s experience through responses to that question, to get the perspective 'from the inside' from those who have traveled the female leadership path. Finally, we end this section examining only the female CEOs' responses to a larger set of the interview schedule questions. 


\section{Claiming the Corner Office: Female CEO Careers}

\section{Men Advising Women}

Of the 139 male CEOs we interviewed, only one tenth insisted that they would advise the same to women as to men. Differences focus on three areas they saw as having most relevance to women: career timing and barriers to promotion, including work-family tradeoffs; attitudes toward risk; and questions of personal demeanor unique to women - specifically, displays of femininity.

\section{Career Timing and Barriers to Promotion}

Male CEOs were well-aware of the difficult trade-offs that come with childbearing in particular. Only one denied this was an issue. A more common attitude was, “...there have to be some sacrifices along the way. And to think that it's not the case is just ... you're setting yourself up for failure” [123]. They also acknowledged that "the majority of childrearing tasks and household tasks still fall on women ....” [123] and stressed the issue of timing:

"the age that they would be raising a family ... is probably the most formative time in making it up the executive ladder. The time when you were building that very deep credibility and experience that then subsequently sets you up to take on a CEO job” [149].

Stepping out of the workforce puts women out of sync with their cohort, with knock-on effects for promotion due to missed developmental experiences: "without those experiential steps I can't put them there, they don't qualify” [037]. One CEO went so far as to say, "if you are planning on having leadership positions, maybe twenty-five to thirty is too early for motherhood" because, "the result is going to be path-dependent" [129].

\section{Mentoring and Sponsorship}

Others felt the challenge was not insurmountable, but pointed toward a need for innovative human resource policy. They called on organizations to provide support systems to retain female talent during years away from the workforce. In particular, they spoke of a single point of 


\section{Claiming the Corner Office: Female CEO Careers}

contact, a special variation of mentor, "somebody in the company who feels responsible for keeping the connection to the person, feels responsible for developing them further" [036].

This theme of mentors and sponsorship highlighted another difficulty: “Women probably need more sponsorship than men” [164], yet, “They have to learn from people who have made the same progression they've made as opposed to me [male CEO]” [168]. But assigning female mentors to young career women can backfire:

"we had a women's group, so women senior managers looking after women, and we gave it up because they became totally niched....And the majority [of the men] felt, well that's great, it's not my issue because we've got the women's group" [036].

Women themselves were not always eager to take on the gender-specific mantle of mentor:

"She left...”, and one of the reasons was “'I didn't want to be the initiatives queen”" [037].

\section{Attitudes To Risk}

Another area of difference the male CEOs mentioned was related to their perception of women’s more careful approach to decision making.

"I think a woman needs to be better prepared; she takes more time, has a greater level of detail and consequently has a different time frame in relation to the average man. The woman transcends the array of implications of decisions, while a man tends to restrict in a certain way the side effects of a decision" [126].

This can be a double-edged sword: despite the positive implications of this greater caution, men referred to the perceived downsides of lack of confidence: “many of the women I've worked with have had very high potential but somehow have a lower sense of self-esteem ...” [071].

This lack of confidence was seen to spill over into women's management of their careers:

"I think there is a tendency for women to need to feel like I've checked every box in whatever I think the requirements are for this opportunity ... you've got to be your own advocate in terms of putting yourself in a position for opportunities” [024]. 


\section{Claiming the Corner Office: Female CEO Careers}

\section{$\underline{\text { Personal Demeanor }}$}

Men disapproved of women who were too 'manly'. It was clear that women must toe a fine line, becoming more assertive while retaining their 'femininity'. Women may need to advocate for themselves, but "not in an aggressive, pushy way" [024]. They were advised to "don't check yourself because you're a woman, but maintain your femininity and believe in yourself” [094].

\section{Women Advising Women}

How did the 12 female CEOs' answers to these questions vary from their male counterparts? The surprising answer is, by not as much as one might think, at least in terms of overall themes. They, too, spoke of work-family trade-offs, attitudes toward risk, and personal demeanor. However, this last theme was expressed mostly in terms of a need for greater self-confidence and resilience, a call for women to accept their own leadership potential.

\section{$\underline{\text { Career Barriers }}$}

One surprising finding was the extent to which female leaders had taken charge when confronted with work-family conflicts, and how little outside support they expected.

"Choose the man you marry very carefully [...] it isn't a joke.[...] work out your domestic trade-offs ... When I was younger, I paid virtually everything I earned to make sure that I didn't have to worry about whether [my child] was left at the gate at childcare" [003].

Their message about re-entering the workforce was more optimistic than their male peers’:

"Stay the course... a lot of people think that if you miss out on a few years in your career here and there, it's the end of the world. [...] it is not. Frankly, in a career of thirty years, thirty-five years, forty-five years, one, two, three, four, five, six years matter - they don't" [166].

\section{Confidence Barriers}

Women saw women as having the same flaws as the male CEOs did, particularly in the area of personal ambition, which was hampered by persistent low self-esteem in spite of high 


\section{Claiming the Corner Office: Female CEO Careers}

potential. While acknowledging the setbacks child-raising could bring, they blamed women themselves for at least part of the disparity between men's and women's rates of advancement: “ $I$ think we widen that gap because they [men] start pushing for promotions much harder and faster than we do" [117]. They advocated greater boldness, calling on women to "think of themselves as leaders" and "not hesitate to ask" [166]. Developing confidence is a critical first step for women in accepting their potential for promotion.

\section{Toughening Up}

Like their male peers, female CEOs sometimes said women should develop thicker skin:

"...if you have a performance evaluation, men take the feedback and they sift through it and they go 'OK, putting that in the bin'.... What do we [women] do? ... We ruminate, we might cry [...] Maybe not take things quite as seriously, just have a bit more fortitude in that regard" [117].

To summarize the findings from our gender-specific probe, we see the women in our sample have successfully navigated the work-family conundrum, learned to embrace risk, and struck an ‘acceptable' balance between assertiveness and femininity in order to become CEOs in an environment where their progress was largely dependent on convincing their predominantly male managers of their suitability for promotion. While the men and women we interviewed viewed the barriers to women’s advancement along similar themes, there were some variations, particularly about demeanor: men called for women to retain and display their femininity, and women called for women to assert themselves more and 'own' their potential as leaders. Thus their responses to this gender-specific probe foreshadow the themes that emerged from the interviews with female CEOs. The rest of the findings section focuses exclusively on the 12 female CEOs, presenting data from their full interviews. We find evidence that working with the 'self' is critical for women in getting and doing the job of CEO, and we organize the findings 


\section{Claiming the Corner Office: Female CEO Careers}

into self-acceptance, self-management, and self-development. Each theme includes both contextual conditions and personal experiences and behaviors.

\section{Self-Acceptance}

Given the advice female CEOs shared about the need for women to accept themselves as potential leaders and to approach their career development with greater self-confidence, we sought to explore how these women came to see themselves as leaders. A main theme that emerged related to self-acceptance as a key first step on the path to the corner office.

\section{Defining Moments of Leadership}

Since we were interested in how interviewees had developed their leadership potential over time, we asked whether CEOs had defining experiences that shaped them as leaders. We found that the women mostly emphasized work-related experiences rather than personal ones. Their defining moments occurred once they were adults and embarked on a career, and the lessons learned can be grouped into two categories. One relates to personal development, such as seeking continuous self-improvement, pushing one’s own limits and having perseverance, being bold by taking risks and feeling comfortable with the unknowable, living with purpose and trusting others. The second category relates to the performative and/or operational aspects of their work such as learning how to run a business, have a global perspective, develop their communication and shift one's leadership lens towards a top-down and outside-in view of the organization.

Typically, these were positive and focused on their human capital development, with CEOs citing, for example, profit and loss responsibilities and international postings. Other experiences were (at the time) negative. For instance, one said that:

"I had a major stumble about five years ago, actually seven years ago in my professional career, I was demoted and at the time I definitely thought my path was done” [117] . 


\section{Claiming the Corner Office: Female CEO Careers}

What made a defining moment was not whether it was positive or negative, but the opportunity it provided to turn the experiences into personal lessons for improvement.

\section{$\underline{\text { Career Barriers }}$}

While we did not ask our female interviewees to define what career or career success mean for them, they did refer to these concepts. For instance, the female CEOs in our sample described their career as transitions of not just roles but also mental transitions as they assumed leadership positions, with one female CEO describing a "[lens] shift from a bottom up to a top down and an outside-in and when that happens ... people make the shift from being managers to leaders” [166]. This CEO, like several others, also stressed that career is a collection of experiences that involves seeking diverse experiences in order to develop themselves as leaders. They emphasized the need for women to make conscious decisions because " $[y]$ ou do it for yourself, your own education, for your own self-content of life, [...]. Therefore go for it seriously...” [091]. Passing work hurdles such as successfully completing a difficult assignment or persevering after a failure are seen by female CEOs as small successes paving their way to the C-suite. A female CEO said:

“Leadership is built day by day, month by month and year by year." [117].

A constant theme across the interviews was the challenge for women to find balance, especially between the incongruous demands of their personal and professional lives. While our CEOs took work-life balance issues seriously, they framed work-life decisions like other business decisions: recognize the need to make trade-offs, make a choice, accept the responsibilities that come with it, and move on. 


\section{Self-Development}

Self-development refers to processes whereby female CEOs learn to lead and draw on resources from their environment to grow for their own and their organization’s benefit.

\section{Developing ‘Big Picture’ Capabilities}

To win the corner office, CEOs had to develop strategic capabilities, including becoming comfortable making decisions with inadequate information or preparation. This involves learning to prioritise time and effort, thinking big, and avoiding micro-management: "Choose your hill to die on. [...] don't try and fix everything, choose the things that really matter if you're going to put, you know, your energy into getting them right” [137].

In contrast to prior research, which depicts female leaders as relatively weak in their strategic thinking, these CEOs place great emphasis on strategy, vision and purpose:

“... be absolutely clear on what their [i.e., the CEOs'] purpose is, what the company's vision or mission is and what the values are and being true to that...have very clear values and that you live, eat and breathe those values every day" [110].

Others talked of strategy in terms of taking a long-term perspective, as well as having sufficient organizational agility to recalibrate the vision both of the CEO and of the leadership team when necessary.

\section{Networking}

Rather than seeing networking as an opportunity to build political capital, female CEOs referred to the purpose of networks as providing challenge and helping see an issue under a different light. For them networking has a distinctive purpose and fits their leadership style:

"There have been two people in my business career that really have given me good analysis [...] branching out ideas, you know, branching out ideas in an analytical manner and then bringing up issues that you probably yourself would never think of. ...” [091]. 


\section{Claiming the Corner Office: Female CEO Careers}

However, none counted on a sponsor for career success:

"[Women] shouldn't wait for others to include them, and pull them along, and take them to the positions they deserve to fill because of the talent and ability they possess" [130].

Another said: “women tend to go more for mentors, men tend to go more for advocates” [117].

Rather, they emphasized trying to develop networks that would help them do their current job better, rather than to get a better job, which is typically how men employ networks. They typically referred to their networks as potential sources of information to help them resolve organizational issues or make more informed decisions. Even as CEOs, where such networks range from board members, to advisors or other CEOs and the CEO’s team, the focus was primarily on using them to accomplish their own role effectively.

\section{Mentoring}

This relates to the co-creation of developmental opportunities by mentoring and being mentored. The female CEOs emphasized how they developed relationships that help them improve their leadership skills and serve as resources for more informed organizational decisions. This support was especially important because female role models were - and remain - rare. Five CEOs referred to some kind of mentor (often informally) who provided them with career advice; two referred to a coach for themselves or for their colleagues and two described their mentors as being also their career sponsors who provided the necessary support and resources for their career development:

"I had a mentor who believed in women, and I came in in strategy but he quickly, after I led also acquisitions, moved me into line jobs running businesses” [078].

Whether or not they had themselves had female role models, the female CEOs in this study recognized an obligation to help other women develop as leaders, with one stating female leaders 


\section{Claiming the Corner Office: Female CEO Careers}

“...should be women who are prepared to pull other women up with them. [...] At the end of the day, our sex also has to support itself” [130]

\section{Trend toward Transformational Leadership Style}

Female CEOs’ perceptions about their own performance in the role broadly support prior findings that women's leadership style is more transformational. Yet, our data also refine and extend these by showing women's active role in developing their leadership capacity. CEOs seek to communicate their vision and empower subordinates to achieve organizational goals:

"It's about how they [i.e., the CEOs] make other people behave in their presence. So, you know, do they inspire people to, you know, set their own vision, like do they, or do they create a vision that enables people to set their own playing field and stretch goals and the way that they're going to operate to achieve optimum outcomes. You know, do they create an environment where people are encouraged to give each other feedback and coaching so that they can actually collectively and individually achieve a lot more than they would otherwise” [004].

Others talked of the importance of role modeling their idealized behaviors to their colleagues. At the same time, the CEOs’ preferred leadership style also had a strong nurturing element, which some attributed to work-family balance that might also have acted as a barrier in their earlier years: “...having the kids [...] gives you that softer side and that you have to be able to relate to people” [078].

Nurturing also involves developing an environment that encourages diverse thinking. The transformational leadership style was reflected in female CEOs’ strong emphasis on listening and communication. Communication is important for information sourcing and learning but also for spreading the CEO’s vision within the organization. Leading effectively requires a combination of analytics and intuition:

"I often summarize this as the ability to do unnatural acts. [...] you have to have the intellectual capacity to be able to create clarity out of complexity and to be able to balance [...] the intuitive and emotional elements with the high core analytics..." [004]. 


\section{Claiming the Corner Office: Female CEO Careers}

Another talked about being a "big believer in STEM [Science, Technology, Engineering, Mathematics] education and analytics” [078]. Such analytical skills are important and seen as typical of males.

\section{Self-Management}

Having accepted their potential as leaders, the CEOs described how they seek to manage their personal demeanor and how their own experiences are aimed at 'toughening up'. Contextually they also talked about their attitudes towards risk and building resilience over time.

\section{$\underline{\text { Personal Demeanor }}$}

With "more and more pressure on CEOs to be more truthful and more genuine” [069], a recurring self-management theme was how they seek to be authentic and focused on their purpose. They discussed the struggle between maintaining their authentic self and toning down any behavior that may come across as too 'masculine'. For women, their multiple life and work roles and identities mean they may be drawn to behave in ways that contradict each other, and finding a balance can be challenging, such as how to be suitably assertive, without being perceived as "pushy”.

Another balancing act a CEO mentioned was learning to adjust the pace and timing of her assertiveness to be better able to achieve organizational buy-in, while maintaining her true self:

"I would learn quickly, but I also would push for change [...]you want to be who you are and drive for change..., but yet you can't. You're not there to upset the applecart 100\%” [078].

This would often require adjustment of style to fit followers' needs and situation, but delivered in a way that her identity as leader was not challenged:

“... aligning with them at the right time at the right moment whenever necessary [...] trying to make up a good team where I am still the boss” [091]. 


\section{Claiming the Corner Office: Female CEO Careers}

\section{Toughening up}

Consistently female CEOs talked about having to toughen up over time under the pressure of building a career and taking on the CEO role. Toughening up was necessary because, as we showed above, women typically lacked confidence and felt under-qualified for senior positions, relative to men. It partly involved mastering the physical stress of a demanding career:

"There is nothing in business that is easy coming in [...] while you are doing it, please don't pity yourself. Please don't think how much time ... and how tired you are....” [091].

Others talked about building an optimistic and confident outlook and the resilience-building effects of positive outcomes: "when you win, your win will be a lasting one and that's what you need to remember” [069]. Female CEOs’ self-management also involves coping with others’ unfavorable perceptions or prejudice and having self-awareness to recognize your own limits: “...CEOs need to be incredibly well-rounded [...] smart enough to know that you're not the smartest” [117].

\section{Expectations about Risk-Taking}

Paying conscious attention to a tendency for perfectionism and risk aversion, the female CEOs actively worked on pushing their limits and learning from mistakes and failures. They said they keenly sought particular experiences to further their career, including exposure to international/multi-cultural environments, profit and loss responsibility and different roles. Mirroring the advice to female aspirants, a CEO talked about actively seeking a senior role with increased responsibilities:

“... a learning is, for me personally [...] to ask for the job. [...] I actually went up and asked for one of the top jobs in the company [...] don't just wait for things to happen [166]. 


\section{Claiming the Corner Office: Female CEO Careers}

In spite of these stretching experiences, they noted that no experience could adequately prepare them for the demands of the role as a CEO; as a former Chief Operating Officer said:

"it's funny when you're in second chair and you think like 'oh I'm doing all the things a CEO is doing', and the truth is you're not and being in the first chair feels a lot different...” [117].

Pushing, or being pushed, to their own limits was a common theme to build personal resilience and cope with failure. CEOs talked about the importance of being “...in a permanent state of un-readiness [...] or preparation for the unexpected” [117] and becoming comfortable with uncertainty over time because “...if you're risk-averse you're the wrong person for the job” [003].

While acknowledging the importance of creative discussion, their risk-management approaches conveyed a strong analytical flavour:

"I rattle the scenarios through in my head probably constantly for like, you know, a week before and that includes day and night, so I always feel sleepless” [003].

To summarize, we found that across all three areas of 'self-work' there was a strong transformational theme in how these female CEOs lead others that involves nurturing and communicative behavior (stereotypical feminine) as well as role modeling, confirming prior research. However, we also found evidence of strategic thinking and a sense of comfort in uncertainty and risk (stereotypical masculine). Similarly, our data show that these CEOs combine strongly analytic methods with intuition and reflection. Most significantly, we found that achieving this leadership style was not the natural result of being female; rather, it resulted from continual reflexivity and 'self-work'. This began early on in their careers, when they first encountered contextual and personal barriers; in fact, 'transforming' their own attitudes to accept their leadership potential was a key first step to developing the mindset and skills to later become CEOs. As they rose through the ranks, they continually examined themselves and their behavior, 


\section{Claiming the Corner Office: Female CEO Careers}

learned to self-manage, developed skills and found ways of expressing themselves that adequately met contextual expectations while still allowing them to get the job done. Though the contextual conditions they encountered were demanding, these women’s narratives reveal strongly agentic self-work aimed at achieving social and organizational fluency, career engagement, and fluidity in performed interpretations of stereotypical gendered behaviors. As these female CEOs advanced from 'getting the CEO job' to being 'on the job', each 'self' theme would become more or less prevalent. Self-acceptance emerged early in their careers to become the driving force for their future career trajectory, whereas self-management and selfdevelopment have been more prevalent interchangeably as these women grew to more senior roles and into the corner office.

\section{Discussion}

We now develop practical recommendations on (1) how female leadership candidates can gradually progress their careers towards the corner office (see grey chevrons in Figure 1) and (2) how HR departments can support each step at a personal and policy level (see white shapes in Figure 1). In essence, the personal-level recommendations relate to intra-organizational HR practices to help individual female employees progress their careers, whereas the policy-level recommendations relate to actions at the organizational or institutional level that may change the HR field and the opportunities women have across organizations and cultures.

\section{Insert Figure 1 about here}

Further, by putting our findings in dialogue with the human resource management (HRM) 


\section{Claiming the Corner Office: Female CEO Careers}

literature and the gender and leadership literature, we distill three interrelated theoretical contributions: First, we highlight the critical impetus of women's active ownership of their leadership career and the need for HR practice to facilitate the underlying process of selfacceptance by supporting active ownership and the 'long game' female leadership candidates must play (left chevron in Figure 1). Second, we propose the concept of gynandrous leadership. We argue that in their self-development, female CEOs should embrace being both feminine and masculine. Yet, they should actively put their femininity (gyne) first and make it the basis of their leadership (central chevron in Figure 1). HR practice can support them at a personal level, by helping them build new networks, and at a policy level, by institutionalizing the gynandrous leadership model. Third, for successful female CEOs to ‘own’ their leadership, the selfmanagement of their gynandrous style should not simply rely on incorporating stereotypically male behaviors into their leadership repertoire. Instead, female leaders translate leadership to blend masculine leadership behaviors with their own (right chevron in Figure 1). In short, we shift focus from how female leaders may do different things, to how they do the same things, but differently. Critically, we still lack an adequate vocabulary to do justice to the leadership variants successful female leaders have developed. We therefore call upon HR research and policy to fill this void and draft a new leadership lexicon.

\section{Self-Acceptance}

In our interviews, we were struck by how female CEOs described the earliest moments of their leadership careers. In particular, their accounts of how they recognized their leadership ambition and potential sounded like a 'coming out' - a moment of self-acceptance. Paradoxically, female CEOs have to accept, rather than celebrate their leadership potential. As shown in Table 1, self-acceptance emerges from the confrontation of personal leadership experiences, ambitions 


\section{Claiming the Corner Office: Female CEO Careers}

and barriers with contextual pressures and expectations. Women's self-acceptance as (potential) leaders is a crucial step toward active ownership as the key impetus for female leadership careers as illustrated by its position as the starting point of our process model in Figure 1. It allows aspiring female CEOs to take charge of the progress and destiny of their leadership journey (selfdevelopment), and the execution of their new role (self-management).

\section{$\underline{\text { Recommendation for aspiring female CEOs: Take Active Ownership }}$}

Taking active ownership is critical for female leadership careers, as they pivot on two points: What female leaders become - and what they don't. The latter is salient as women face the difficult work-life trade-offs any leader faces, but also often encounter criticism for prioritizing their career over family from those who still endorse traditional gender roles (Davidson \& Fielden, 1999; Greenhaus \& Beutell, 1985). Therefore, the female CEOs noted that prioritizing their own development over that of others - especially their families - required a particularly selfaccepting and effortful choice of what they would become, what they would give up, and the criticisms they would face.

Furthermore, while de-prioritizing family has commonly been counter-cultural for women, so has pursuing a leadership journey. Such a journey is not only a matter of ambition, but also of (self)-perceived ability. Only one female respondent recounted “defining moments" of their leadership that predate their career, echoing literature on gendered patterns of career relevant experiences (e.g., Fitzsimmons et al., 2014; van Staveren, 2013). Hence, female leadership candidates face two barriers early on: Others may presume that they have fewer relevant experiences and would not consider them as a serious candidate (Rowley et al., 2015), and women may struggle to see their own ability, leading them to underrate their own leadership performance (Paustian-Underdahl et al., 2014). This “neurotic impostor” syndrome (Kets de 


\section{Claiming the Corner Office: Female CEO Careers}

Vries, 2005) means that female leadership candidates are less likely to put themselves forward; but they are also less likely to be considered by others. Hence, our CEOs encouraged young women not to wait until they feel completely ready for a job. Instead, they should seek stretch assignments for their development, that is: take active ownership. Our sample's rallying call is: “Don’t wait to be asked - take charge!”, hence we interpret ownership in a very agentic sense and as a prerequisite for self-development.

\section{HR Departments: Support Active Ownership and Support the 'Long Game'}

Some of our respondents credited moments of adversity and perseverance (e.g., Doherty, 2012) or experiences of bad bosses, learning and a resolve to do better (e.g., Lubin, 2016) as the 'defining moments' of their leadership. However, not all women have the inner strength or external support to turn a regressive behavior into a positive learning experience. Clearly, there is a crucial role for HR departments to empower talented women and support active ownership. As CEOs in our sample noted, this could be by recognizing talent and offering female candidates onthe-job opportunities to expand their leadership skills.

While the concept of empowerment remains poorly operationalized in day-to-day HRM practices (Lincoln et al., 2002), and the sensemaking of gendered leadership is often enacted into organizational policies with variable results (Hearn \& Piekkari, 2005), leadership development and executive coaching interventions have a positive, empowering effect on their participants (Athanasopoulou \& Dopson, 2015). HR should employ such interventions more actively to boost women's leadership confidence. For instance, formal career management practices could include opportunities for high potential women to participate in structured executive coaching interventions designed jointly with the coach, the HR department and the female coachee's direct report. These interventions could feed back into consequent career progression plans. The HR 


\section{Claiming the Corner Office: Female CEO Careers}

department could work with the coach and candidate to identify where their skills would fit best as they rise through the ranks. Other more informal processes could involve offering female leaders the incentives and resources to pursue executive education training to hone their leadership skills.

At the policy-level, infrastructural HR initiatives can also safeguard that pipelines of future female leaders remain fueled in the long-run. HR policies should support the 'long game' in making career pacing a more central concern. To date, many HR practices continue to "produce and reproduce outdated gender norms” (Mastracci \& Arreola, 2016: 137; Dickens, 1998; Festing et al., 2015). HR systems should change so as to have a long-term focus and offer women the space and time to manage raising a family while pursuing ambitious careers. In the 'long game', as we heard, "miss[ing] out on a few years in your career here and there, it's [not] the end of the world [...] in a career of thirty years, thirty-five years, forty-five years” [166]. Therefore, allowing female leaders to stage phases alternatively dominated by work or family seems profitable for female leaders and their organizations. To achieve this oscillation, HR must offer women ways to remain engaged in the professional and social life of the workplace, even while formally on a reduced workload or leave.

Companies must clearly support a long game approach in their actions, not just their policies. Implementation requires regular assessment to ensure follow-through, but many companies fail to do so (e.g., Tharenou, 2010). HR interventions may be as simple as: establishing family-friendly time management, such as flex-time block-schedules (Steier, 2013); encouraging management skills utilization, which women see as signal of a supportive work environment (Chen et al., 2005); or rolling out HR practices that promote equity and increase employee commitment as well as retention (Spoor \& Hoye, 2014). 


\section{Claiming the Corner Office: Female CEO Careers}

\section{Self-Development}

Supporting the long game not only offers women the time and space to accept their potential as leaders, but also develop the requisite skills. Where lack of self-promotion or sponsorship hamper access to formal development programs, much of this development remains incumbent upon women. It is self-development, either in preparation for, or on the job. Our female respondents explained how they built a more complete leadership repertoire by adopting skills and behaviors which the literature casts as stereotypically masculine. In contrast to the literature on such androgynous leadership (Eagly, 2013), however, our female CEOs clearly presented these stereotypically male skills and behaviors as complements to their own leadership base. In other words, they embrace gynandrous leadership, an encompassing blend of leadership skills and behaviors that puts the feminine (gyne) first and transcends stereotypes. Additionally, CEOs spoke of the contextual influences on their journey, such as the networks they built and the sponsorship they received, suggesting that there is ample room for HR practice to support gynandrous leadership and help aspiring female CEOs build new networks (see central chevron in Figure 1).

\section{Recommendation for Aspiring Female CEOs: Embrace Gynandrous Leadership}

Our female CEOs naturally foregrounded those skills and qualities they felt needed (self-) development. With a firm understanding of where their leadership was anchored, typically in transformational leadership capabilities, they saw other skills as complementary. These other skills were mostly those which the literature describes as stereotypically ‘masculine’ (Kolb, 1999): Having strategic perspective and vision (Ibarra \& Obodaru 2009; Javidan et al., 2016), employing rigorous analytics and extolling the value of 'STEM education' (Science, Technology, Engineering, Mathematics) and lacking “neutral, uncertain and qualified expressions of 


\section{Claiming the Corner Office: Female CEO Careers}

judgment” (Ibarra \& Petriglieri, 2007: 14). In fact, our respondents did not use such gendered terms, pointing to a discrepancy between the leadership literature and the language successful female leaders use to present themselves.

The exemplars of female leadership we showcase should serve as a corrective to the widespread “implicit masculine bias” (Ho et al., 2015). The combination of skills our female CEOs foreground - vision, analytics, risk-taking - makes for more self-sufficient CEOs, especially when paired with transformational leadership skills. Even then, though, a more 'complete’ leadership skillset remains critical for female CEOs. As Johnson et al. (2008) note, men are considered effective leaders when they display strength, or stereotypically masculine leadership traits. Yet, to receive comparable evaluations, women must additionally display sensitive, feminine behaviors. Our respondents emphasized how stereotypically masculine skills complemented the more stereotypically feminine ones they had retained.

Consequently, our female leaders offer counter-examples to common definitions of androgyny, which stress gender ambiguity or uncertainty. We do not find a "dissociation of female leaders from their feminine qualities” (Eagly \& Johannesen-Schmidt, 2007: 284). The gynandrous leadership concept, thus, more closely echoes Kolb (1999: 307), who reserves the term androgynous for those "who score above the mean” on both masculinity and femininity scales. Contrary to the concept of androgyneity, successful female CEOs put their feminine (gyne) leadership base first. Gender could be better understood as a negotiated and (re)created practice within an organizational context rather than a demographic, reflecting stereotypes and perpetuating inequalities (Leitch \& Stead, 2016:127). 


\section{Claiming the Corner Office: Female CEO Careers}

\section{HR Departments: Help Build New Networks and Institutionalize Gynandrous Leadership}

While the leadership literature extols the virtues of androgynous leadership, it remains less clear how women access new skills or incorporate them into a form of gynandrous leadership. HR functions can support this transition by helping women build new networks for their personal advancement and by institutionalizing gynandrous leadership at a policy level.

As more women rise to senior leadership positions, positive "trickle-down” effects can help develop more inclusive work environments with more female role models (OECD, 2012: 176). Future female leaders are unlikely to be the lonely pioneers our female CEOs were, but this does not automatically translate into more developmental environments for women. While men and women are equally likely to be mentors (Ragins \& Scandura, 1994), mentees get picked based on potential or ability, rather than need for help (Allen et al., 2000). With women being less likely to self-promote or be recognized for their relevant experience, they may be less likely to be selected for mentoring. It is therefore important to configure HR interventions that help women signal their leadership potential, attract successful mentors, and build new networks.

Building new networks is particularly important for two reasons: First, given their own relatively less influential positions, women have limited access to networks with significant political capital (Hopkins \& O’ Neil, 2007). Strikingly, our data suggests this problem persists even when women make it to the CEO position. Second, women must be more qualified than men to be considered for senior roles, such as board membership, let alone the CEO role (Groysberg \& Bell, 2013); therefore, there is a greater demand for self-development opportunities. This is exactly what women typically use networking for: grow on the job, gain new knowledge, become better leaders. In short, they network to continuously self-develop. This distinguishes them from men who use networking more "strategically and instrumentally”, primarily for career advancement (Broadbridge, 2010: 815; see also Shortland, 2011). Currently, 


\section{Claiming the Corner Office: Female CEO Careers}

leadership development initiatives do not pay much attention to the role of gender in the effective development of networks (Cullen-Lester et al, 2016). Given women’s natural inclination to network for human rather than political capital, organizations should support leadership highpotentials in building up political capital to help find sponsors, rather than just mentors (Ibarra et al., 2010). Critically, given the differences described above, mixed gender and women-only leadership development programs serve different aims (Sugiyama et al., 2016). Both could benefit women, either to build networks for social support and overcome macho cultures, or to more assiduously build political capital. Offering both options and channeling female candidates towards the personally more salient one would give HR functions a more active role in this field.

At a policy level, HR functions can pursue broader impact by helping institutionalize gynandrous leadership at the organizational level and beyond. Within organizations, HR functions are often the instigators of diversity initiatives or cultural change. Endorsement by top leadership, new mission statements, and redesigned HR policies to promote this emerging model of female leadership are good steps forward. These changes can happen alongside other structural initiatives such as gender quotas. Much, however, depends on the individual-organizational interplay to ensure that chosen initiatives benefit female employees, rather than just the organization. Also, female leaders can play an active role via lobbying, pushing to "level the career playing field” and using male sponsors to influence organizational policies, attitudes and behaviors (Hopkins \& O’Neil, 2007: 146). In doing so, change initiatives shift focus from organizational to individual needs (Diehl \& Dzubinski, 2016).

To have a lasting effect on broader areas of society, an institutional level change is needed to change how we define leadership - gendered or not. HR functions can initiate institutional collaborations such as cross-sector partnerships with academia, governments, or policy bodies, or they can engage in initiatives in the World Economic Forum, or Women on Boards. Doing so 


\section{Claiming the Corner Office: Female CEO Careers}

could broaden the global female talent pool or at least encourage good management practices and accountability to facilitate female empowerment (OECD, 2012). As bottom-up HR champions of this new agenda, companies can help embed women's leadership development within systemic gender equity initiatives (Bilimoria \& Liang, 2012; in Debebe et al., 2014).

\section{Self-Management}

Gynandrous leadership resonates with calls for women to act against gender stereotypes and employ more stereotypically male leadership behaviors (e.g., Budworth \& Mann, 2010). However, this is not without risks, as female leaders may be penalized for doing so (Rudman et al., 2012; Amanatullah \& Tinsley, 2013). We, therefore, argue that successful female leadership careers pivot on the self-management of this delicate balance, as illustrated by the right chevron in Figure 1. Specifically, it requires women to translate leadership: Women do not simply adopt male leadership traits or behaviors, but make them their own; they translate them. However, as we noted from the language used by our CEOs, our current vocabulary does not accurately reflect such translations. Instead, it perpetuates stereotypes and gendered leadership approaches. In fact, lacking alternatives, we found ourselves using some of that language here. We had to draw on existing literature on gender and leadership, only to introduce the argument that we need to break free of such stereotypical vocabulary. Consequently, we argue that HR functions not only have a role to support leadership translations, but also to draft a new leadership lexicon.

\section{$\underline{\text { Recommendation for Aspiring Female CEOs: Translate Leadership }}$}

Our female CEOs talked about competing expectations such as having to 'be the boss', but 'not too pushy'. This highlights a key challenge in the self-management of gynandrous leaders: The more incongruous a leadership role feels, the harder it is to 'own' it. Even the successful female CEOs in our sample concede that some 'masculine' leadership behaviors are more 


\section{Claiming the Corner Office: Female CEO Careers}

difficult to enact than others and pose a greater risk of being penalized for adopting them. The solution which they have fashioned extends our understanding of androgynous leadership: To avoid the risk of inconsistency and suspicion, they do not combine different gender stereotypes in their pure form by oscillating between them. Instead, they blend them into their gynandrous leadership repertoire by translating stereotypically masculine behaviors and performing them in a way that feels authentic. We begin to transcend existing gender stereotypes by shifting focus from how female CEOs do different things compared to their male peers, to how they do the same things, but differently. Harrison’s (2016: 81) leadership-as-practice take on defining leadership as an improvisational art form, “where creative interpretation meets and responds to uncertainty and unpredictability”, could be a fitting way to explain how women embrace leadership and adjust to their role in their distinctive gynandrous style. Differences in role enactment are not novel in this literature (e.g., Eagly \& Johannesen-Schmidt, 2007; Eagly, 2013), but we extend the notion of 'enactment' or 'performance' from broad roles to specific activities. For instance, in the context of how to be 'the boss' without being 'pushy', our CEOs avoid alternating between stereotypically female empathy and stereotypically male assertiveness. Instead, they employ empathetic assertiveness; or, as we playfully call it, 'empassertiveness’. In doing so, they fashion a more gynandrous blend, rather than alternating between masculine and feminine behaviors over time. Arguably, both enacted separately and to their extremes can be equally dysfunctional, bordering on bullying or accommodation, respectively. Empathetic assertiveness is a gynandrous blend that allows leaders to assert themselves in a more functional way, i.e., without causing unnecessary offense.

Likewise, our respondents indicated that women network differently than men in terms of both their approach and goals. On the surface, every leader networks to extend or deepen personal relationships; in other words, to build social capital. Men typically use such social 


\section{Claiming the Corner Office: Female CEO Careers}

capital to enhance their political capital, while women use it to develop their human capital. Crudely put: women predominantly use networks to learn for the benefit of their organization, while men use them to get themselves promoted. In the end it is 'what you know' versus 'who you know'. We noted that while these dynamics unfolded under the surface, on the face of it, all these activities still fall under the 'networking' label. Nevertheless, the way women CEOs enact networking varies as performed on the ground - in our CEOs’ own words, from “develop[ing] connections" [117] to “continuing to develop knowledge and sharing” [009] and from "surrounding yourself with of a lot of good people” [078] to having "a cluster of [trusted] people” [069]. It also explains why on the surface similarities between male and female leaders outweigh their differences (e.g., Powell, 1990; Vinkenburg et al., 2000). While many leadership behaviors are called the same, the way male and female leaders enact them varies. We therefore call for female leaders to find ways to 'own' their leadership and not be forced into incongruity.

\section{HR Departments: Support Leadership Translations and Craft a New Leadership Lexicon}

Our female CEOs talked about adjusting their behavior to create their own leadership style, for instance, by moderating the timing of their assertiveness to maintain their true self and appear neither too masculine nor too malleable. While striking this fine balance, women risk getting caught in a vicious cycle, navigating expectations to imitate male leadership behavior and the identity conflict that results from enacting incongruent behaviors. This causes stress, impacts performance and often confirms negative views about them as leaders (Bray, 2013). Hence, women may self-undermine unless HR supports gynandrous leadership and the relevant leadership translations.

Examples of useful HR initiatives that support women in translating leadership abound: From the careful design of job-advertisements (Askehave, 2010), to recruitment processes that target 


\section{Claiming the Corner Office: Female CEO Careers}

leaders with non-stereotypical styles, to designing appraisal and promotion systems rewarding gynandrous leadership. While such initiatives are not new in the field, their focused approach to a gynandrous leadership model would be new. HR staff would work with female talent to identify roles that allow testing and evolving this unique style of leading. Executive coaching interventions embedded within HR career development practices could help female leaders to get rid of regressive behaviors, nurture their identity as leaders, and get comfortable with their leadership style.

Finally, we urge HR departments and leadership developers to draft a new leadership lexicon. Simpson et al. (2017: 13) argue that leadership talk is "transformative” and "changes the trajectories of conversations”, producing "new movements in the emergence of practice”. It is therefore important to pay more attention to how this leadership talk translates into HR practices. The current lexicon dates back to the days when established ways of leadership were gendered as predominantly male (Stead, 2014). Hence, if we are serious about women 'translating' leadership to authentically own it and about overcoming the "think manager-think male” mantra (Schein et al., 1996; Ryan \& Haslam, 2007), we need a new language. Otherwise, we argue (see also: Stead, 2014) that by using established - masculine - leadership terminology we obscure the advances women have made in this male-dominated domain.

More dramatically, phenomena are constituted by how we talk about them. The labels we use not only describe, but shape how we think about leadership. The language used in job ads, HR policies and practices, day-to-day workplaces, and even academic literature is a subtle - yet pervasive and powerful - manifestation of second-generation bias whereby work structures and practices covertly put women at a disadvantage (Ibarra et al., 2013). Even the discourse used in leadership textbooks is found to perpetuate “hegemonic (heteronormative) visions of leadership”, which should be recognized and addressed to make leadership a "more equitable and inclusive 


\section{Claiming the Corner Office: Female CEO Careers}

practice” (Ferry, 2017: 3). HR functions should be pioneers in removing avoidable barriers of this kind by choosing language that is more gender-neutral at least and more encouraging of a variety of leadership approaches at best.

In our discussion, we began to introduce new terminology based on the language of female CEOs in our study: empassertiveness as more accurately capturing the nature of women's enactment of 'strength'; ownership of the leadership role as more accurate and feasible than authenticity; 'develop knowledge and sharing' with 'trusted' individuals as better words for the networking that has become tainted by politicking or self-advancement. Why not embrace 'gynandrous' leadership, giving women a vocabulary to match their style and translation of male behaviors? As a field, we must unlearn the gendered language we are used to and reflect deeply on the language we use - and want to develop for the future.

\section{Conclusions: Limitations and Implications for Future HR Research}

From our interviews with 12 female global CEOs we have distilled a series of theoretical contributions and practical suggestions for aspiring CEOs and the HR functions. Echoing the personal accounts of these CEOs, these revolve around: self-acceptance, self-development, and self-management. Jointly, they explain how successful female CEOs initiate their career, control its trajectory, and execute in their role. Future research could bring together HR professionals and female leaders to explore what interventions from those we have suggested (and more) would best help female leadership talent development in each of the three areas of self-work identified here, as well as the new vocabulary that needs to be developed.

Therefore, this study can serve as an important building block for future HR empirical research. As a conclusion, we consequently acknowledge the limitations of our study and explain 


\section{Claiming the Corner Office: Female CEO Careers}

how these limitations can serve as opportunities for new research paths. We then specifically discuss how researchers with larger samples can take this research forward.

While 12 interviewees may seem a relatively small number - compared to the larger sample of 139 male interviewees - it perfectly reflects the small percentage of female CEOs globally (Grant Thornton International, 2016). In line with our qualitative research philosophy, we do not make any statistical claims that hypothesis testing on large-n datasets would allow. Instead, we use the personal, in-depth nature of our data to explore successful career approaches and derive practical suggestions for HR to support talented females in writing their own success story. Still, we acknowledge limitations in our study and suggest avenues for future research to remedy these.

First, as cold-calling CEOs for a qualitative study was unrealistic, we accessed our sample via prior relationships from three sources: a leading executive search firm, a business school alumni base, and personal networks. We acknowledge the dependency of our sample on prior relationships. However, to moderate any adverse effects or impressions of a convenience sample, we started from a list of almost 1,000 contacts and then purposively targeted interviewees so as to build a globally balanced sample that covers a maximal diversity of industries and countries. To further avoid biases from relationship owners, each interview was co-conducted by two interviewers and data analysis was conducted by a research team with no prior relationships to any CEOs in the sample. Related to this, a second limitation in our study is that the accounts we present are the 'success stories' of women who managed to break the glass ceiling - and did so in some of the largest corporations globally. In that sense, we miss out on data from those other women who either fell through the ranks or never reached the glass ceiling. While in-depth interviews with business elites will always remain scarce, future research with a longitudinal qualitative design following the career trajectories of aspiring female CEOs could provide unique insights into the personal and contextual drivers of female success - and failure. We also think 


\section{Claiming the Corner Office: Female CEO Careers}

there is value in more research on best HR practices supporting women's career development, echoing Johnson \& Tunheim’s similar call (2016), with a view to further refine and improve the opportunities offered to women for career progression.

We specifically encourage comparative studies of best practice that account for differences in organization, industry, or culture. This would allow to build on this study drawing on larger samples. Here, we have specifically aimed at CEOs of some of the largest corporations globally. The organizations we studied have large HR departments and due to the scale of their business are expected to have access to some of the best practices in the field. Future research with expanded samples could look into identifying best practices in female talent development in smaller organizations that have less resources. Action research that involves the collaboration of HR and gender scholars with HR practitioners with a view to exchange best practices across organizations of different types and sizes could lead to innovative new HR practices to nurture female leadership talent.

Furthermore, due to the small number of female interviewees in our study, we did not have the opportunity to delve into cultural differences in the career trajectory of female CEOs. National culture and socioeconomic effects were unlikely to have an effect on such a sample of female CEOs running organizations of a global scale. Studies drawing on larger samples of female CEOs from organizations of different sizes and industries could offer a comparative analysis with a view to identify the common threads and variations that culture and other socioeconomic factors play with regard to these women's experiences and most importantly how these women respond to them in different contexts. For instance, several studies recently have showed that many HR gender-friendly practices often fall short of producing substantial positive outcomes when implemented, despite being designed with every good intention (e.g. RajanRankin, 2016; Lee Cooke \& Xiao, 2014; Wheatley, 2012; Aizzat Mohd \& Khor Lee, 2008). 


\section{Claiming the Corner Office: Female CEO Careers}

Understanding the drivers behind such variations by drawing on larger samples of participants and looking into how women respond to them could offer important contextual insights.

Future HR research should be designed in a way that allows to build on and further unpack the three self-themes we identified in this study. We observed that self-acceptance emerges early in female CEOs' careers and becomes the driving force for their future career trajectory. On the other hand, self-management and self-development are interchangeably more evident as these women obtain more senior roles. We need to better understand how the HR departments can develop customised interventions to women who are at different stages in their career to better nurture the most pressing 'self' themes at each stage. HR studies should look into what types of HR interventions should target high potential female employees at an early stage in their career to help them better anchor their self-acceptance. They should also look into what other - differenttypes of interventions can be introduced for women who are at mid-level in the career ladder where the focus - according to our study findings - is more on their development of selfmanagement and self-development. We have provided some suggestions here but this is a terrain that needs further in-depth investigation. Future HR researchers would need to work closely with HR departments to identify what practices facilitate each of these 'self' themes. Again, action research may be a particularly plausible research strategy allowing HR researchers and HR professionals to experiment and track outcomes from such interventions. There needs to be more focus on context and the collection of longitudinal data. Overholt \& Jamrog's (2006) call for contextual thinking in HRM with data evaluated within their real context such as the situation, location, gender, age as well as the predominant and the minority culture is particularly relevant here.

Such HR research also needs to be more anchored to psychology. Recent research on gender and leadership has approached the study of women's leadership development as identity 


\section{Claiming the Corner Office: Female CEO Careers}

development (Ely et al., 2011; Sugiyama et al., 2016; Ibarra \& Petriglieri, 2007). According to Hopkins \& O’Neil (2007: 134) women define career success as much based on internal criteria such as "a sense of contribution, personal fulfillment and integrity" as on "external tangible measures such as compensation and title”. As we found in this study, the way women internalize their experiences and work to overcome any personally- and externally-imposed constraints is of paramount importance on how their career path unfolds. Since the development of the 'self' themes are about how women work with themselves to become better and more confident leaders, the psychology research and practices could offer a wealth of background on which HR scholars could draw. For instance, psychology research heavily draws on the use of personality assessment and skills development inventories. HR researchers could employ such methods to identify the profiles of high potential women at different career stages and their personal and career needs and then analyse them in conjunction to the three 'self' themes identified in this study. Different HR interventions may be more appropriate to different female leaders depending on their personality, their needs and career stage. The three 'self' themes could help HR scholars to explore the design of more customised HR interventions as compared to those offered nowadays where female talent is considered as one homogeneous group.

Last but not least, we aspire that the present study will serve as a testament to the fact that top female leaders see themselves and their role in their organizations and society as being defined beyond the conceptual contraints that discussions on glass ceiling and structural barriers and facilitators pose. They instead stressed how they worked with themseleves to become better professionals and leaders and hence, successfully navigate their careers considering such contexts. Future HR research - whether with smaller or larger samples of participants than ours needs to move beyond the study of the structures and the constraints these pose to women and look more into the power of agency: namely, the women themselves. The focus should be on 


\section{Claiming the Corner Office: Female CEO Careers}

how the HR departments can support them as they draft their own leadership destiny. For instance we need to understand better how empowerment can be translated into HRM practices, and future research could help in that direction.

We believe that more micro-level, longitudinal, interdisciplinary and action-oriented HR and gender and leadership research is the key to producing new and more relevant insights to female leadership talent and its development into the $21^{\text {st }}$ century.

\section{REFERENCES}

Aizzat Mohd., N., \& Khor Lee, H. (2008). The influence of support at work and home on workfamily conflict: does gender make a difference?. Research \& Practice In Human Resource Management, 16(1), 18-38.

Allen, T. D., Poteet, M. L., \& Russell, J. A. (2000). Protege selection by mentors: What makes the difference?. Journal of Organizational Behavior, 21(3), 271.

Amanatullah, E. T., \& Tinsley, C. H. (2013). Punishing female negotiators for asserting too much...or not enough: Exploring why advocacy moderates backlash against assertive female negotiators. Organizational Behavior \& Human Decision Processes, 120(1), 110-122.

Arnold, J., \& Johnson, K. (1997). Mentoring in early career. Human Resource Management Journal, 7(4), 61-70.

Arthur, M. B., \& Rousseau, D. M. (Eds.) (1996). The boundaryless career: A new employment principle for a new organizational era. New York: Oxford University Press.

Askehave, I. (2010). Communicating leadership: a discourse analytical perspective on the job advertisement. Journal of Business Communication, 47(3), 313-345. 


\section{Claiming the Corner Office: Female CEO Careers}

Athanasopoulou, A. \& Dopson, S. (2015). Developing leaders by executive coaching - practice and evidence. Oxford: Oxford University Press.

Bass, B. M., Avolio, B. J., \& Atwater, L. (1996). The transformational and transactional leadership of men and women. Applied Psychology, An International Review, 45, 5-34.

Bilimoria, D., \& Liang, X. (2012). Gender equity in science and engineering: advancing change in higher education. New York, NY: Routledge.

Blaikie, N. (2000). Designing social research. Cambridge: Polity Press

Bray, N. (2013). Morons and oxymorons: Undermining Women in Leadership. INSEAD Knowledge Publications, 1-3.

Brescoll, V. L. (2011). Who Takes the floor and why: gender, power, and volubility in organizations. Administrative Science Quarterly, 56(4), 622-641.

Broadbridge, A. (2010). Social capital, gender and careers: evidence from retail senior managers. Equality, Diversity \& Inclusion, 29(8), 815-834.

Budworth, M., \& Mann, S. L. (2010). Becoming a leader: the challenge of modesty for women. Journal of Management Development, 29(2), 177-186.

Collinson, D. (2017). Critical leadership studies: A response to Learmonth and Morrell. Leadership, 13(3) 272-284.

Chen, Z., Takeuchi, N., \& Wakabayashi, M. (2005). Managerial skill utilization: work environment, gender, and training incentive. International Journal of Human Resource Management, 16(5), 786-808.

Cook, A., \& Glass, C. (2014a). Above the glass ceiling: When are women and racial/ethnic minorities promoted to CEO?. Strategic Management Journal, 35(7), 1080-1089.

Cook, A., \& Glass, C. (2014b). Women and Top Leadership Positions: Towards an Institutional Analysis. Gender, Work \& Organization, 21(1), 91-103. 


\section{Claiming the Corner Office: Female CEO Careers}

Creswell, J. W. (2003). Research design: qualitative, quantitative, and mixed methods approaches. Thousand Oaks, CA: Sage.

Cullen-Lester, K. L., Woehler, M. L., \& Willburn, P. (2016). Network-based leadership development. Journal of Management Education, 40(3), 321-358

Davidson, M. J., \& Fielden, S. (1999). Stress and the working woman. In G. N. Powell (Ed.), Handbook of gender and work: 413-426. Thousand Oaks, CA: Sage.

Day, D. V. (2000). Leadership development: a review in context. Leadership Quarterly. 11(4), 581-613.

Debebe, G., Bilimoria, D., Vinnicombe, S., \& Anderson, D. (2014). Special issue: women’s leadership development programs: lessons learned and new frontiers. Journal of Management Education, 38(4), 608-611.

Dickens, L. (1998). What HRM means for gender equality. Human Resource Management Journal, 8(1), 23-40.

Diehl, A. B., \& Dzubinski, L. M. (2016). Making the invisible visible: a cross-sector analysis of gender-based leadership barriers. Human Resource Development Quarterly, 27(2), 181-206.

Dobbins, G. H., \& Platz, S. J. (1986). Sex differences in leadership: How real are they? Academy of Management Review, 11, 118-127.

Doherty, P. (2012). Leading the way. Business Strategy Review, 23(1), 10-16.

Douglas, C. (2012). The moderating role of leader and follower sex in dyads on the leadership behavior-leader effectiveness relationships. Leadership Quarterly, 23(1), 163-175.

Druskat, V. U. (1994). Gender and leadership style: Transformational and transactional leadership in the Roman Catholic Church. Leadership Quarterly, 5(2), 99-119. 


\section{Claiming the Corner Office: Female CEO Careers}

Eagly, A. H. (2013). Women as leaders: leadership style versus leaders' values and attitudes.

Harvard Business School Research Symposium - Gender \& Work: Challenging Conventional Wisdom.

Eagly, A. H., \& Johannesen-Schmidt, M. (2007). Leadership style matters: The small, but important, style differences between male and female leaders. In D. Bilmoria \& S. K. Piderit (Eds.), Handbook on women in business and management (pp. 279-303). Northampton, MA: Edward Elgar.

Eagly, A. H., Johannesen-Schmidt, M. C., \& van Engen, M. (2003). Transformational, transactional, and laissez-faire leadership styles: A meta-analysis comparing women and men. Psychological Bulletin, 129, 569-591.

Eagly, A. H., \& Karau, S. J. (2002). Role congruity theory of prejudice toward female leaders. Psychological Review, 109, 573-598.

Eagly, A. H., Makhijani, M. G., \& Klonsky, B. G. (1992). Gender and the evaluation of leaders: A meta-analysis. Psychological Bulletin, 111, 3-22.

Eisenhardt, K. M. (1989). Building theories from case study research. Academy of Management Review, 14(4), 532-550.

Elsesser, K., \& Lever, J. (2011). Does gender bias against female leaders persist? Quantitative and qualitative data from a large-scale survey. Human Relations, 64(12), 1555-1578.

Ely, R. J., Ibarra, H., \& Kolb, D. M. (2011). Taking gender into account: theory and design for women's leadership development programs. Academy of Management Learning \& Education, 10(3), 474-493.

Festing, M., Knappert, L., \& Kornau, A. (2015). Gender-specific preferences in global performance management: an empirical study of male and female managers in a multinational context. Human Resource Management, 54(1), 55-79. 


\section{Claiming the Corner Office: Female CEO Careers}

Ferry, N. C. (2017). It’s a family business!: Leadership texts as technologies of heteronormativity. Leadership, 0(0) 1-19.

Fitzsimmons, T. W., Callan, V. J., \& Paulsen, N. (2014). Gender disparity in the C-suite: do male and female CEOs differ in how they reached the top?. Leadership Quarterly, 25(2), 245-266.

Glass, C., \& Cook, A. 2016. Leading at the top: Understanding women's challenges above the glass ceiling. Leadership Quarterly, 27(1), 51-63.

Grant Thornton International Business Report (IRB) 2016. Women in Business: Turning Promise into Practice. Source:

http://www.grantthornton.global/globalassets/wib_turning_promise_into_practice.pdf (Accessed on October 6th 2016).

Greenhaus, J. H., \& Beutell, N. J. (1985). Sources of conflict between work and family roles. Academy of Management Review, 10, 76-88.

Groysberg, B., \& Bell, D. (2013). Dysfunction in the boardroom. Harvard Business Review, 91(6), 88-95.

Groysberg, B., \& Abrahams, R. (2014). Manage your work, manage your life. Harvard Business Review, 92(3), 58-66.

Harrison, R. T. (2016). Leadership, leadership development and all that jazz. Leadership, 13(1), 81-99.

Hearn, J., \& Piekkari, R. (2005). Gendered Leaderships and Leaderships on Gender Policy: National Context, Corporate Structures, and Chief Human Resources Managers in Transnational Corporations. Leadership, 1(4), 429-454.

Ho, S., Li, A., Tam, K., \& Zhang, F. (2015). CEO Gender, ethical leadership, and accounting conservatism. Journal of Business Ethics, 127(2), 351-370. 


\section{Claiming the Corner Office: Female CEO Careers}

Hopkins, M. M. \& O’ Neil, D. A. (2007). Women and success: dilemmas and opportunities. In Bilimoria, D. and Piderit, S. K. (eds). Handbook on women in business and management. (pp. 132-153). Cheltenham: Edward Elgar Publishing Ltd.

Hyde, J. S. (2014). Gender similarities and differences. Annual Review of Psychology, 65(1), 373-398.

Ibarra, H. (2011). Locked out of the boardroom. INSEAD Knowledge Publications, 5(4), 9.

Ibarra, H., \& Obodaru, O. (2009). Women and the vision thing. Harvard Business Review, 87(1), $62-70$.

Ibarra, H., \& Petriglieri, J. (2007). Impossible selves: image strategies and identity threat in professional women's career transitions. INSEAD Working Papers Collection, 69, 1-35.

Ibarra, H., Carter, N. M., \& Silva, C. (2010). Why men still get more promotions than women. Harvard Business Review, 88(9), 80-86.

Ibarra, H., Ely, R. \& Kolb, D. (2013). Educate everyone about second-generation gender bias. HBR Blog Network. August 21, 2013. Accessed on September 14 ${ }^{\text {th }}, 2013$ at: http://blogs.hbr.org/2013/08/educate-everyone-about-second/

Ibarra, H., \& Petriglieri, J. L. (2010). Identity work and play. Journal of Organizational Change Management, 23(1), 10-25.

Inkson, K., Gunz, H., Ganesh, S., \& Roper, J. (2012). Boundaryless careers: Bringing back boundaries. Organization Studies, 33(3), 323-340.

Javidan, M., Bullough, A., \& Dibble, R. (2016). Mind the gap: gender differences in global leadership self-efficacies. Academy of Management Perspectives, 30(1), 59-73.

Johnson, E., \& Tunheim K. (2016). Understanding the experiences of professional women leaders living and working in Sweden. Advances In Developing Human Resources,18(2), 169-186. 


\section{Claiming the Corner Office: Female CEO Careers}

Johnson, S. K., Murphy, S., Zewdie, S., \& Reichard, R. J. (2008). The strong, sensitive type:

Effects of gender stereotypes and leadership prototypes on the evaluation of male and female leaders. Organizational Behavior \& Human Decision Processes, 106(1), 39-60.

Kakabadse, N. K., Figueira, C., Nicoloupoulou, K., Yang, J. H., Kakabadse, A., \& Ozbilgin, M. F. (2015). Gender diversity and board performance: women's experiences and perspectives. Human Resource Management, 54(2), 265-281.

Kanter, R. M. (2013). The interplay of structure and behavior: how system dynamics can explain or change outcomes by gender or social category. Harvard Business School Research Symposium - Gender \& Work: Challenging Conventional Wisdom.

Kets de Vries, M. F. R. (2005). The dangers of feeling like a fake, Harvard Business Review, 83(9), 108-116.

Koenig, A. M., \& Eagly, A. H. (2014). Extending role congruity theory of prejudice to men and women with sex-typed mental illnesses. Basic \& Applied Social Psychology, 36(1), 70-82.

Koenig, A. M., Mitchell, A. A., Eagly, A. H., \& Ristikari, T. (2011). Are leader stereotypes masculine? a meta-analysis of three research paradigms. Psychological Bulletin, 137(4), 616642.

Kolb, J. A. (1999). The effect of gender role, attitude toward leadership, and self-confidence on leader emergence: implications for leadership development. Human Resource Development Quarterly, 10(4), 305-320.

Kossek, E. E., Su, R., \& Wu, L. (2017). “Opting Out” or "Pushed Out”? Integrating perspectives on women's career equality for gender inclusion and interventions. Journal of Management, 43(1), 228-254.

Leck, J., \& Orser, B. 2013. Fostering trust in mentoring relationships: an exploratory study. Equality, Diversity \& Inclusion, 32(4), 410-425. 


\section{Claiming the Corner Office: Female CEO Careers}

Lee Cooke, F., \& Xiao, Y. (2014). Gender roles and organizational hr practices: the case of women's careers in accountancy and consultancy firms in China. Human Resource Management, 53(1), 23-44.

Leitch, C. \& Stead, V. (2016). Special Issue of Leadership: Gender and Leadership (Call for papers). Leadership, 12(1) 127-128

Lincoln, N. D., Travers, C., Ackers, P., \& Wilkinson, A. (2002). The meaning of empowerment: the interdisciplinary etymology of a new management concept. International Journal of Management Reviews, 4(3), 271.

Locke, K. D. (2001). Grounded theory in management research. London: Sage.

Lopez-Zafra, E., Garcia-Retamero, R., \& Berrios Martos, M. (2012). The relationship between transformational leadership and emotional intelligence from a gendered approach. Psychological Record, 62(1), 97-114.

Lubin, S. (2016). How women CEOs overcame bad jobs, bad bosses. The Wall Street Journal. Source: http://www.wsj.com/articles/how-women-ceos-overcame-bad-jobs-bad-bosses$\underline{1476615782}$. Accessed on October 16, 2016.

Marshall, C., \& Rossman, G. B. (1999). Designing qualitative research (3 ${ }^{\text {rd }}$ ed.). Thousand Oaks, CA: Sage Publications, Inc.

Martin, P. Y., \& Turner, B. A. (1986). Grounded theory and organizational research. Journal of Applied Behavioral Science, 22(2), 141-157.

Mastracci, S., \& Arreola, V. I. (2016). Gendered organizations: how human resource management practices produce and reproduce administrative man. Administrative Theory \& Praxis, 38(2), 137-149. 


\section{Claiming the Corner Office: Female CEO Careers}

McDonald, M. L., \& Westphal, J. D. (2013). Access denied: low mentoring of women and minority first-time directors and its negative effects on appointments to additional boards. Academy of Management Journal, 56(4), 1169-1198.

Mulcahy, M., \& Linehan, C. (2014). Females and precarious board positions: further evidence of the glass cliff. British Journal of Management, 25(3), 425-438.

Northouse, P.G. (2016). Leadership: Theory and Practice ( $7^{\text {th }}$ ed.), London: Sage.

OECD. (2012). Gender equality in employment. Closing the gender gap: act now. OECD Publishing.

Overholt, M., \& Jamrog, J. (2006). Why contextual thinking is vital. Strategic HR Review, 5(6), 7.

Paustian-Underdahl, S. C., Slattery Walker, L., \& Woehr, D. J. (2014). Gender and perceptions of leadership effectiveness: a meta-analysis of contextual moderators. Journal of Applied Psychology, 99(6), 1129-1145.

Powell, G. N. (1990). One more time: do female and male managers differ? Academy of Management Executive, 4(3), 68-75.

Pratt, M. G. (2009). For the lack of a boilerplate: tips on writing up (and reviewing) qualitative research. Academy of Management Journal, 52(5), 856-862.

Pratt, M. G., Rockmann, K. W., \& Kaufmann, J. B. (2006). Constructing professional identity: the role of work and identity learning cycles in the customization of identity among medical residents. Academy of Management Journal, 49(2), 235-262.

Raelin, J. A. (ed.) (2016) Leadership-as-Practice: Theory and Application. NY: Routledge.

Ragins, B. R., \& Scandura, T. A. (1994). Gender differences in expected outcomes of mentoring relationships. Academy of Management Journal, 37(4), 957-971. 


\section{Claiming the Corner Office: Female CEO Careers}

Rajan-Rankin, S. (2016). Paternalism and the paradox of work-life balance: discourse and practice. Community, Work \& Family, 19(2), 227-241.

Rosener, J. B. (1990). Ways women lead. Harvard Business Review, 68(6), 119-125.

Rowley, C., Lee, J. K., \& Lan, L. L. (2015). Why women say no to corporate boards and what can be done: “ornamental directors” in Asia. Journal of Management Inquiry, 24(2), 205207.

Ruderman, M. N., Ohlott, P. J., Panzer, K., \& King, S. N. (2002). Benefits of multiple roles for managerial women. Academy of Management Journal, 45(2), 369-386.

Rudman, L. A., Moss-Racusin, C. A., Phelan, J. E., \& Nauts, S. (2012). Status incongruity and backlash effects: Defending the gender hierarchy motivates prejudice against female leaders. Journal of Experimental Social Psychology, 48, 165-179.

Ryan, M. K., \& Haslam, S. (2007). The glass cliff: exploring the dynamics surrounding the appointment of women to precarious leadership positions. Academy of Management Review, 32(2), 549-572.

Sabharwal, M. (2015). From glass ceiling to glass cliff: women in senior executive service. Journal of Public Administration Research \& Theory, 25(2), 399-426.

Schatzki, T., Knorr Cetina, K., \& Von Savigny, E. (eds.) (2001). The practice turn in contemporary theory. London: Routledge.

Schedlitzki, D., Case, P., \& Knights, D. (2017). Ways of leading in non-Anglophone contexts: Representing, expressing and enacting authority beyond the English-speaking world. Leadership, 13(2): 127-132.

Schein, V. E., Mueller, R., Lituchy, T., \& Jiang, L. (1996). Think manager - think male: a global phenomenon?. Journal of Organizational Behavior, 17(1), 33-41. 


\section{Claiming the Corner Office: Female CEO Careers}

Shortland, S. (2011). Networking: A valuable career intervention for women expatriates? Career Development International, 16(3), 271-292.

Simpson, B., Buchan, L., \& Sillince, J. (2017). The performativity of leadership talk. Leadership. 0(0), 1-18.

Spoor, J. R., \& Hoye, R. (2014). Perceived support and women's intentions to stay at a sport organization. British Journal of Management, 25(3), 407-424.

Stead, V. (2013). Learning to deploy (in)visibility: An examination of women leaders’ lived experiences. Management Learning, 44(1), 63-79.

Stead, V. (2014). The gendered power relations of action learning: a critical analysis of women's reflections on a leadership development programme. Human Resource Development International, 17(4), 416-437.

Steier, G. (2013). Thinking win-win: boosting profitability through gender-balanced flex-time. Cornell HR Review, 1-16.

Sugiyama, K., Cavanagh, K. V., van Esch, C., Bilimoria, D., \& Brown, C. (2016). Inclusive leadership development. Journal of Management Education, 40(3), 253-292.

Tharenou, P. (2010). Women's self-initiated expatriation as a career option and its ethical issues. Journal of Business Ethics, 95(1), 73-88.

Thomas, R. J. (1993). Interviewing important people in big companies. Journal of Contemporary Ethnography, 22(1), 80-96.

van Engen, M. L., van der Leeden, R., \& Willemsen, T. M. (2001). Gender, context and leadership styles: A field study. Journal of Occupational \& Organizational Psychology, 74(5), 581-598.

Van Staveren, I. (2013). An exploratory cross-country analysis of gendered institutions. Journal of International Development, 25(1), 108-121. 
Vinkenburg, C. J., Jansen, P. G. W., \& Koopman, P. L. (2000). Feminine leadership: A review of gender differences in managerial behaviour and effectiveness. In M. J. Davidson \& R. J. Burke (eds.), Women in management: Current research issue, Vol. II (pp. 121-137). London: Sage.

Welbourne, T. M. (2012). Editor-in-chief's note: research methods in human resource management: critical knowledge for practitioners and academics. Human Resource Management, 51(1), 1-2.

West, C., \& Zimmerman, D. H. (1987). Doing gender. Gender and society, 1(2), 125-151.

Wheatley, D. (2012). Work-life balance, travel-to-work, and the dual career household. Personnel Review, 41(6), 813-831.

Whittington, R. (2002). The work of strategizing and organizing: For a practice perspective. Strategic Organization, 1(1), 119-127.

Yin, R. K. (2013). Case Study Research: Design and Methods. Thousand Oaks, CA, Sage Publications, Inc.

Zenger Folkman Inc. Report. (2011). Women vs. men in leadership.

Zenger, J., \& Folkman, J. (2012). Are women better leaders than men? HBR Blog Network. (Accessed September 12 ${ }^{\text {th }}$, 2013). Source:

http://blogs.hbr.org/cs/2012/03/a_study_in_leadership_women_do.html\#.T3. Full report available at: http://zengerfolkman.force.com/hbrarticle2012 


\section{Appendix I: Invitation Letter and Interview Schedule}

\section{Invitation letter}

Dear $[\ldots]$,

As you may know [executive search firm] recently announced a research partnership with [Business school]. The initial research initiative which has just been launched, aims to better understand what qualities CEOs need to succeed in today's volatile and often contradictory world. The research results will be showcased at next year's [global non-profit foundation organizing an annual forum] in [location]. As part of this global research initiative, we will be speaking with and meeting roughly two hundred CEOs from around the world and asking them specifically -

\section{'How do CEOs develop the competence to lead in a changing world?'}

We would be extremely honored and grateful if you would agree to participate in the research and to contribute your insights to this groundbreaking piece of research. The research interview will last between 45 and 60 minutes and will focus on three complementary areas: The leadership challenges the next generation of CEOs will face; The qualities and capabilities they will need to tackle those challenges; The formal and informal ways by which CEOs develop these capabilities. In this latter part, we are particularly interested in your own personal development journey and your experience of 'defining moments' that shaped your leadership.

If you elect to participate we would like to audio record the interview to ensure that your statements are captured fully and accurately. We will ask your express permission to record prior to the interview and share a verbatim transcript for your own records afterwards. We guarantee the confidentiality of your statements by storing all recordings securely at the [name of University] and anonymizing all transcripts prior to analysis. Data will only be used in an anonymized and non-attributable form, unless you give express permission to be quoted personally. They will inform a report for the [global non-profit foundation organizing an annual forum] 2015 in [location], scholarly publications on leadership, as well as new tools and methodologies for leadership development.

Please let me know if you would be willing to participate and I will make the necessary arrangements. Thank you in anticipation of your support.

Warm regards, 


\section{Interview Schedule}

1.Have you already seen a change in the roles and responsibilities of CEOs? Can you give some examples of those changes?

2. Given these changes, what do you believe are the most critical qualities and tools needed by the CEO of the future?

-What would be your key pieces of advice to your successor?

-What help should any successor to your role be given to attain those qualities?

-What do you wish you had known before taking your current position?

3. How do you prepare yourself for uncertainty and change?

-Where do you look for insights into what the future might hold?

-How do you recognize situations where established ways of thinking prove inadequate?

-Examples of success and failure?

4.What is the toughest decision you have had to make during your time as CEO?

-What specifically made that situation so difficult? Also compared to others, e.g., peoplerelated; risk; compliance; 'big bets'?

-How did you make that decision (process)?

-How did that decision affect you personally? What was your lesson learned?

5.How would you describe your feelings just before making a major decision in which there is a high degree of uncertainty and high stakes?

-Do you ever doubt yourself?

-How do you cope with that situation - professionally and personally?

-What are the sources of support [systems, peers, family] you draw on in these situations?

- How do you approach the next challenge like this?

6. Looking back over your life so far, what do you personally consider the defining moments that shaped you as a leader?

-How did this experience, and follow up reflection, help you become a better leader?

-Is the same process important for future leaders?

7.What is the best advice you have ever been given?

-How do you use that in your daily work?

-Any piece of advice which proved wrong, or that has become outdated, given today's world?

8.Looking a bit further into the future, what would be your message to any aspiring CEOs in class of undergraduates starting today?

-What would you specifically advise the female students or your daughter? 
9.Just to get some context [(a) based on the short survey you completed, I see you identified $x, y, z$ as...] [(b) What do you expect to be...] the global trends that you expect to challenge your business in the next 3-5 years?

-Where do these trends come from?

-To what extent do you see yourself as shaping or following those trends?

-Do you expect these trends to change who you feel accountable to? If so, how?

10. Exit Question: Are there any other questions you feel we should have asked, but didn't? 


\section{Table 1. Data structure}

\begin{tabular}{|c|c|c|c|}
\hline First order concepts and illustrative data & $\begin{array}{l}\text { Second order } \\
\text { themes }\end{array}$ & $\begin{array}{l}\text { Locus of } \\
\text { influence }\end{array}$ & $\begin{array}{l}\text { Aggregate } \\
\text { theory } \\
\text { dimensions }\end{array}$ \\
\hline $\begin{array}{l}\text { Professional experiences identified as 'defining moments', not pre-professional or } \\
\text { personal } \\
\text { “... for me to become part of a global company and interact with global people, some who } \\
\text { didn't speak English very well and my French was OK, to have that opportunity to see a global } \\
\text { world in } 1999 \text { when nobody was talking global was, was a defining moment” [078] }\end{array}$ & $\begin{array}{l}\text { Career provides } \\
\text { defining } \\
\text { moments of } \\
\text { leadership }\end{array}$ & Personal & \multirow{6}{*}{$\begin{array}{l}\text { Self- } \\
\text { acceptance }\end{array}$} \\
\hline $\begin{array}{l}\text { Low self-esteem despite high potential } \\
\text { "... women will always tell you there's one thing that they can't do on their CV or on the job } \\
\text { [...] that they're applying for, whereas men will tell you all the things that they can do" [110] } \\
\text { Calling on women to "think of themselves as leaders" } \\
\text { "the biggest issue of women when they go beyond middle management is to have that switch } \\
\text { go off in their minds that they are leaders and, you know, to think of themselves as leaders" [130] } \\
\text { "be a career planner [...] go for it seriously..." [091] }\end{array}$ & $\begin{array}{l}\text { Confidence } \\
\text { barriers }\end{array}$ & Personal & \\
\hline $\begin{array}{l}\text { 'Ask for the job' } \\
\text { “very often it’s a question of often asking [for a leadership job]” [130] }\end{array}$ & & & \\
\hline $\begin{array}{l}\text { 'Can't have everything’ } \\
\text { “... you can't be perfect at everything, so you make trade-offs all the time and you've just got } \\
\text { to work out what are the right trade-offs for you at what point in time” [003] }\end{array}$ & $\begin{array}{l}\text { Career } \\
\text { barriers/tradeoffs }\end{array}$ & Contextual & \\
\hline $\begin{array}{l}\text { Family 'sacrifices' along the way } \\
\text { "I never in my mind thought I wouldn't have kids. I always thought: I want to get my career } \\
\text { going and I want to have kids and then I want to enable my lifestyle ... you know, we have to have } \\
\text { the condo that there's room for a live-in because I knew, you know, you had to have ... I had to } \\
\text { have the environment ... My husband was always traveling. So it was like: "Well, I'm not going to } \\
\text { depend on you. I don't want to have that struggle" [078] }\end{array}$ & & & \\
\hline $\begin{array}{l}\text { Household tasks make careers 'difficult' } \\
\text { “... when you do take something on you go, I mean that's where you go in hearts, guts, mind, } \\
\text { you know, the whole lot, hours, you've absolutely got to give everything ... I think some of the } \\
\text { pieces for women, there are different parts in their lives and they're not able to do that with kids or } \\
\text { other components that hold them back" [099] }\end{array}$ & & & \\
\hline $\begin{array}{l}\text { Vision - being strategic } \\
\text { "balance of short term and long term but always being really clear on the long term” [009] }\end{array}$ & $\begin{array}{l}\text { Developing 'big } \\
\text { picture }\end{array}$ & Personal & \\
\hline
\end{tabular}




\section{Strategic planning}

"... the idea of set and forget ... that as a mindset I think is not the mindset for the future. I think I can't imagine a single business that could think, you know, I've got a great strategy, now we're just going to set and execute for the next, you know, interminable period of time [...] it means strategy is, is more work in progress than definitive" [003]

\section{Ability to avoid micro-managing}

“... take a breath and don't sweat the small stuff, like think about the big issues” [078]

"Choose your hill to die on. [...] don't try and fix everything, choose the things that really matter if you're going to put, you know, your energy into getting them right" [137]

\section{Information seeking}

"[...] glean that input from people around you, you know, surround yourself with really good people because that is how you make the decisions" [078]

\section{Connecting}

"you need to work with people who are distance thinking and around their ability to actually work a collective and collegiate approach to decision making so you have a better identification of the implications of the decision" [004]

\section{Building community}

"... it becomes ever, ever more important that you've got diversity, not in the conventional sense but true diversity of thinking on the team and that they really do operate as a team" [110]

\section{Creating support}

"I had a real risk that I would run to $Z$ and then not paint the alphabet for the team. And so [CEO OF PREVIOUS COMPANY 1] actually sat me down ... and said you're only going to get there, the game here is not to go across the finishing line in the end style, no, you have to get there as a collective and you need to bring the team along with you" [004]

\section{Providing role models}

"work with a good manager who is a leader ... example of a good case[...] is the quickest way of learning" [091]

\section{Pull other women up}

"when I was choosing analytics, you know, there weren't that many role models ... there was a little bit of a stigma ... that stigma, you know, it's still lasted" [078]

\section{Role modeling}

"the more you demand, the more they are able to give you. [...] I try to be more an example myself [...] then if people believe that she is doing that much, why can't I do also a bit more" [091]

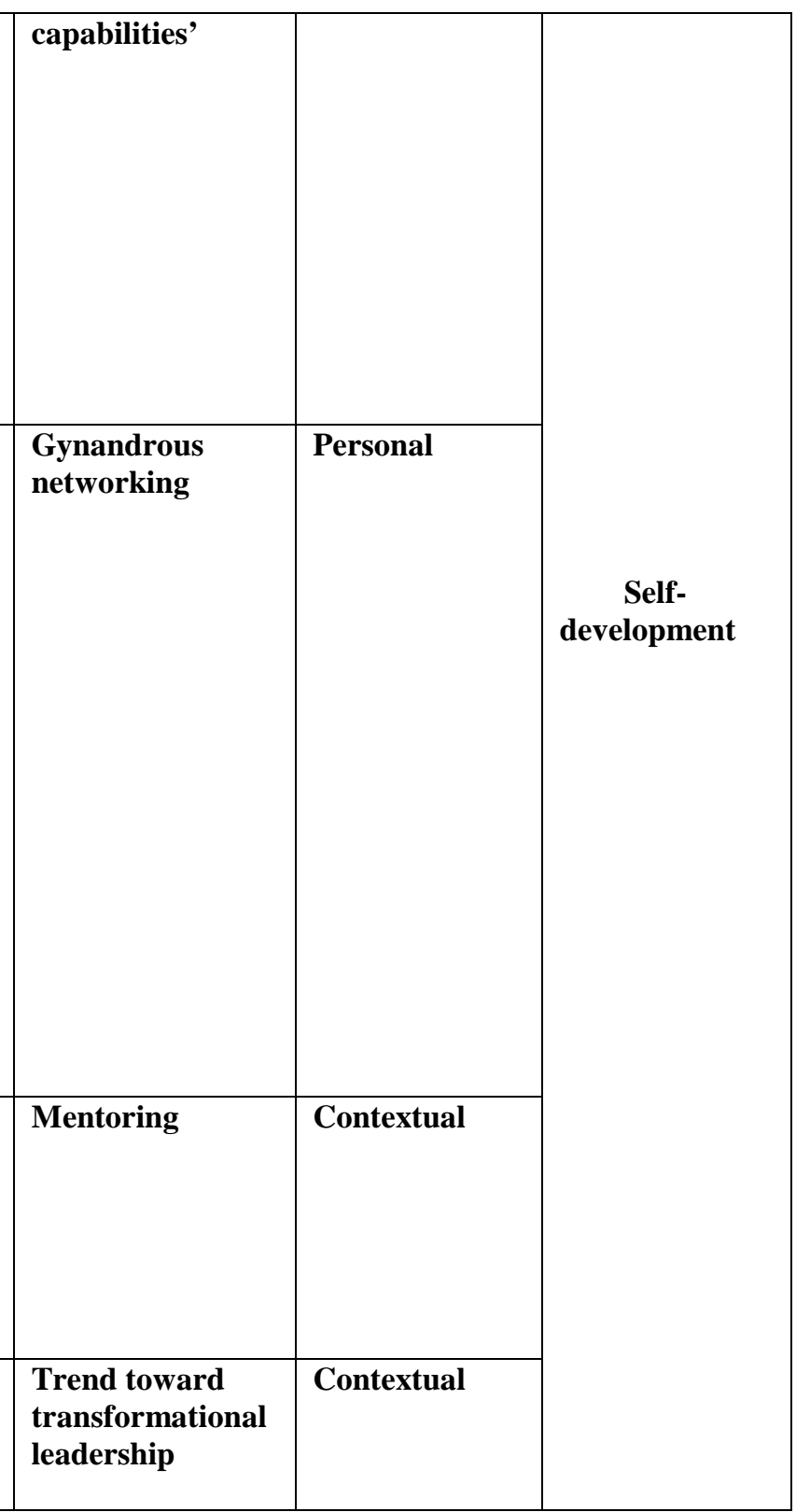




\section{Mix of analytics and intuition}

"to survive as a female Managing Director she'd actually probably had more of the traditional male attributes in the way that she led and impacted ... [she was] a very highly agile, highly capable female executive" [004]

\section{Communicating}

"...that's why I tell the women, this is not about being like the toughest person in the room [...] it's not about who won, it's about compromise" [078]

“... humor's key, making it fun for people. [...] particularly when it's a God-awful environment, absolutely critical, and where you're making fun of yourself ..." [099]

\section{Be the boss}

"I have eventually figured out a way that works for me where someone else is not forcing me to change who I am in order to fit in, but get my voice across" [069]

\section{Not too pushy}

"[...] am I striking the right balance between pushing an agenda strongly and balancing that well with taking people along, and that's always a fine balance. [...] very often there are tradeoffs" [166]

\section{Don't self-promote}

“... [you] don't want to be perceived as pushy, don't want to be seen as self-promoting, always got to feel you're completely qualified for it [...] [099]

\section{Be a good listener}

“... if I could do it over, I would have done [...] more listening sessions, [...] more communications, better communications, deeper communications" [117]

\section{Develop thick skin}

“...lick your wounds for a day and go and redirect”" [117]

\section{Curb need for more detailed preparation}

"I think that it is very important to follow through with absolutely everything that I have outstanding so that it is finished. I think that it is very important to be highly disciplined, very persistent, and, well, clearly to work well, but not necessarily more. The productivity we get when we work well and better, not when we work more" [130]

\section{Attitudes toward risk}

"... I love it, facing challenge and being ready for challenges [...] Challenge is something that brings you out of your comfort zone, right?" [099]

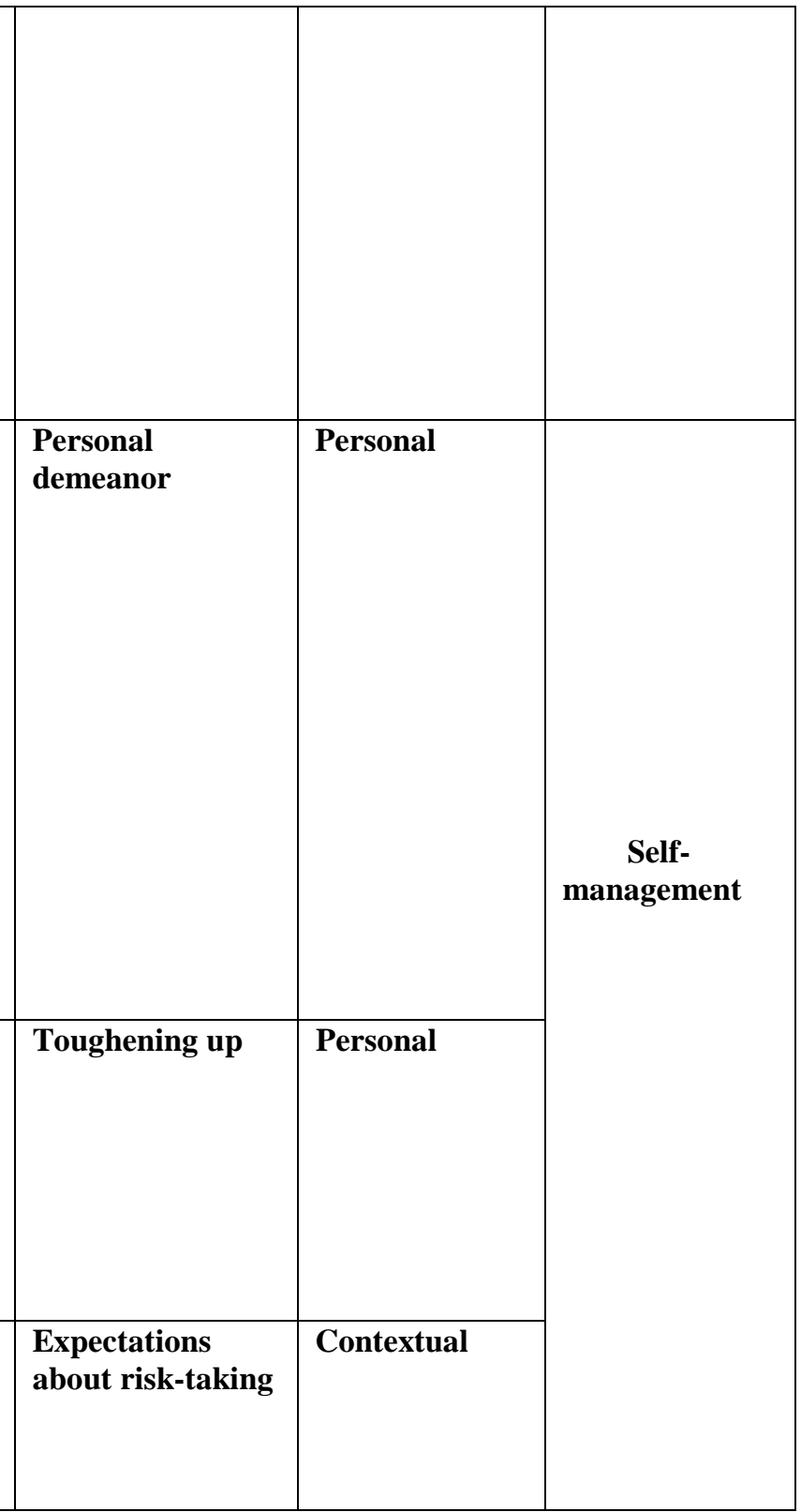




\section{Build resilience}

"I worry that often we try to protect people from hardship when it's actually the hardship that's actually the greatest font of knowledge and resilience, emotional stability” [004]

\section{Cope with uncertainty}

"I think that one of the ways that you get to a far calmer outcome around the decision is to actually map out what could be the local consequences and risks associated with the decision and then what are your mitigants against those risks ... that hopefully gives you a sense of comfort that you're making the right decision" [004]

\section{Push own limits}

“... without really operational difficulties and not knowing how to handle them, not passing through these difficulties - you don't become a CEO” [091]

\section{Seek diverse experiences}

"diversity of exposure [which] ... helps train them in some of these capabilities" [166]

\section{Embrace difficulty}

[...] through many challenges, many obstacles and many failures. [...] this has been what has marked me in my leadership" [117] 
Figure 1: "From candidate to corner office: An integrated process model

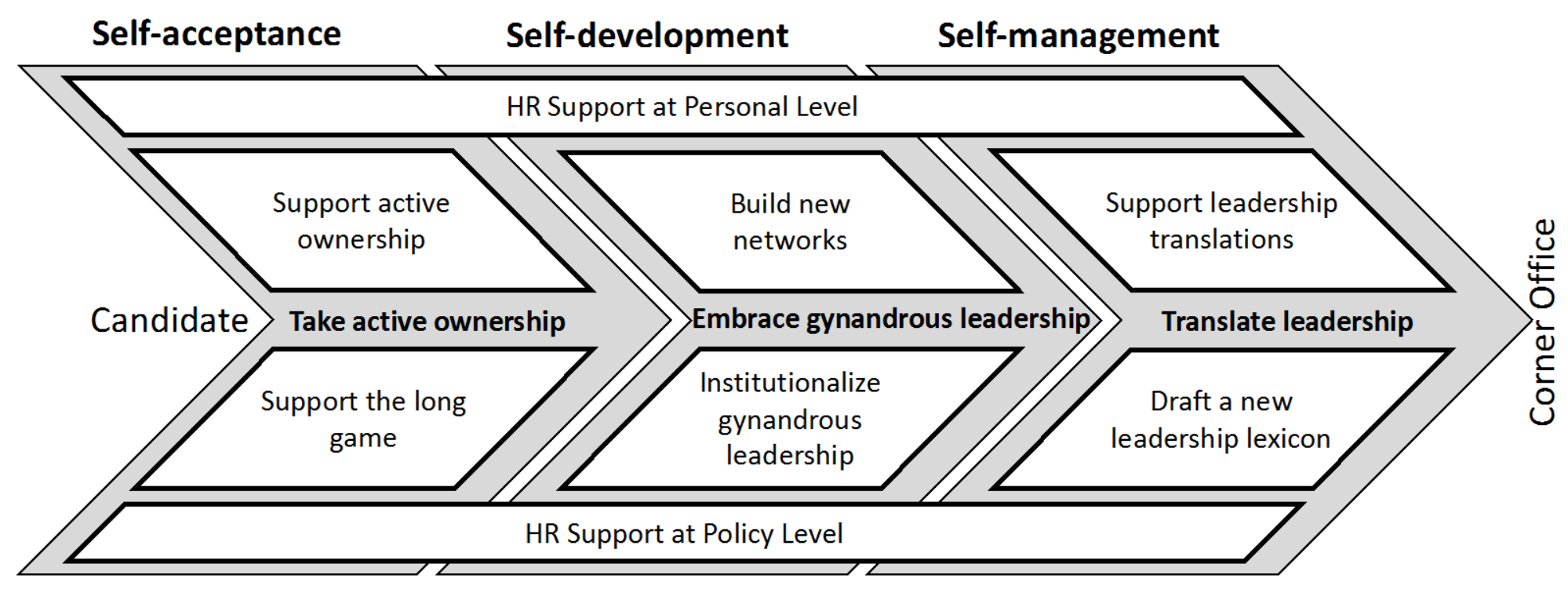


ANDROMACHI ATHANASOPOULOU is an Assistant Professor in Organisational Behaviour at the School of Business and Management, Queen Mary University of London and an Associate Fellow - Executive Education at the Saïd Business School, University of Oxford where she received her doctorate. She previously held research appointments at Harvard University and Oxford University. Her research interests include leadership (CEO role and gender issues) and business ethics. Besides publishing in peer-reviewed journals and book chapters, Andromachi has co-authored a book on executive coaching.

AMANDA MOSS-COWAN is an Assistant Professor of Management at the College of Business Administration, University of Rhode Island. Her research interests include organizational identity, image and roles, organizational crisis and change, interorganizational conflict and collaboration, and business and the natural environment. She earned her doctorate at the Saïd Business School, University of Oxford, with a focus on organizational theory and strategy.

MICHAEL SMETS is an Associate Professor of Management and Organisation Studies at the Saïd Business School, University of Oxford, where he also received his doctorate. His research focuses on leadership, institutional complexity, and professional practice, especially in the context of professional service firms. His research has appeared in leading management journals, including the Academy of Management Journal, Human Relations, and Organization Science, and has been covered by the Financial Times, Forbes, Bloomberg, CNN, CNBC, the Guardian and other international media.

TIM MORRIS is Professor of Management studies at the University of Oxford. He received his doctorate from the London School of Economics. Before joining Oxford University, he was a professor at Imperial College, London. Tim's research interests are concerned with the role and development of Chief Executive Officers and processes of innovation and competitive advantage in professional service firms. He has published extensively in leading journals, including the Academy of Management Journal, Journal of Management Studies, Human Relations and Human Resource Management. 